\title{
Fish population dynamic in the newly impounded Nam Theun 2 Reservoir (Lao PDR)
}

\section{Dynamique des populations piscicoles dans le réservoir nouvellement mis en eau de Nam Theun 2 (Laos)}

\author{
Maud Cottet ${ }^{(1)}$, Stéphane Descloux ${ }^{(2)}$, Pierre Guédant ${ }^{(1)}$, \\ Philippe Cerdan ${ }^{(3)}$, Régis Vigouroux ${ }^{(3)}$ \\ (1) Nam Theun 2 Power Company Limited (NTPC), Environment \& Social Division, Water Quality \\ and Biodiversity Dept., Gnommalath Office, PO Box 5862, Vientiane, Lao PDR \\ (2) EDF - Hydro Engineering Centre, Sustainable Development Department Savoie-Technolac, \\ Le Bourget-du-Lac, France \\ stephane.descloux@edf.fr \\ (3) Hydreco, Lab. Environnement Petit-Saut, BP 823, 97388 Kourou Cedex, French Guyana
}

\begin{abstract}
A fish population monitoring was carried out in the reservoir and tributaries of the hydropower project Nam Theun 2 (Lao PDR) at the end of the warm and dry seasons and at the end of the warm and wet seasons between 2008 and 2013. The study focused on three aquatic systems (river upstream, transition area, and reservoir) and different drowned habitats (dense/light forests and agricultural soils) associated or not with the presence of villages. The reservoir fish population was expected to follow three distinct phases, which should be respectively a rapid increase in biomass and abundance (trophic upsurge) followed by a decline and a stabilization of the population. This succession appeared to be different to the commonly observed scenario in terms of biomass, abundance and taxonomic richness compared to other temperate and tropical reservoirs. The indicator species $(H$. macrolepidota and $P$. carinatus) did not show changes in their size range since impoundment. The presence of structured habitats (e.g. inundated forest) favoured the fish population in terms of biomass and abundance. The fish population in the transition area and the river upstream improved quickly after the impoundment and presented higher taxonomic richness compared to the reservoir. Finally, the transition area appeared to be the most productive area within the Nam Theun 2 Reservoir especially if it remained outside of fishing activities.
\end{abstract}

Key words - fish population, impoundment, neotropical reservoir, habitats

Résumé - Un suivi des populations piscicoles a été réalisé au sein du réservoir hydro-électrique de Nam Theun 2 (Laos) et de ses affluents à la fin de la saison chaude et sèche et à la fin de la saison chaude et humide de 2008 à 2013. Trois systèmes aquatiques ont été étudiés (rivière amont, zone de transition et réservoir) ainsi que différents habitats inondés (forêt dense/clairsemée, sols agricoles) associés ou non à la présence de villages. Il était attendu 
que les populations piscicoles du réservoir suivent une évolution selon trois phases qui devaient être respectivement une croissance rapide des biomasses et abondances des populations piscicoles suivie d'un déclin puis d'une stabilisation des populations. Ces successions sont apparues être différentes des scénarios communément observés dans d'autres réservoirs tropicaux et tempérés en termes de biomasses, abondances et richesses taxonomiques. Les espèces indicatrices choisies (H. macrolepidota et $P$. carinatus) n'ont pas montré de changements majeurs quant à leurs classes de tailles depuis la mise en eau. Il est apparu que la présence d'un habitat structuré (e.g. forêt inondée) favorisait les populations piscicoles en termes de biomasses et d'abondances. Les populations piscicoles des environnements de zone de transition et de rivière amont ont montré une rapide amélioration peu après la mise en eau et ont présenté une richesse taxonomique supérieure à celle du réservoir. Enfin, la zone de transition est apparue comme étant la zone la plus productive au sein du réservoir de Nam Theun 2 surtout quand celle-ci se situait dans une zone extérieure aux activités de pêches.

Mots clés - populations piscicoles, mise en eau, réservoir néo-tropical, habitats

\section{INTRODUCTION}

Over the last decade numerous hydropower projects have been planned/ constructed in Southeast Asia to answer an increasing energy demand. The Mekong basin is known for its high hydropower potential. The number of hydropower projects has been estimated at 200 in the "Greater Mekong Sub-region" area, which includes Thailand, Cambodia, Myanmar, Vietnam, Yunan Province (China) and Lao PDR (Souksavath \& Nakayama, 2013). In 2009, The Mekong River Commission (MRC) estimated that more than $70 \%$ of a total 124 existing, under construction and potential projects in the Lower Mekong Basin are located in Lao PDR (MRC, 2010).

Assessments of environmental changes linked to hydropower projects are studied worldwide in temperate and tropical areas (Lelek, 1973; Petr, 1978; Kubečka, 1993; Poddubny \& Galat, 1995; de Mérona et al., 2001; de Mérona, 2005; Mol et al., 2007;
Agostinho et al., 2008). Three levels of impact on aquatic ecosystems are recognised (Baxter, 1977; Zhong \& Power, 1996). The primary impact is related to the construction of the reservoir itself. After damming, the river continuum is interrupted and a new system is created upstream of the dam. This includes the creation of new habitats such as a pelagic zone and an expanded shoreline. The secondary impact is the change from a lotic to a lentic hydrodynamic system. This leads to a change in physico-chemical features such as a current loss, change in water retention time or the appearance of a thermal stratification. Finally, the tertiary and indirect impact is the consequence of the two first ones. It is defined as a reorganisation of biotic communities with a change in species composition, the trophic structure of the food web (food resource, predators) (Zhong \& Power, 1996; de Mérona et al., 2001; de Mérona et al., 2003; Yi et al., 2010; de Freitas Terra \& Araújo, 2011) and obviously a change in fish 


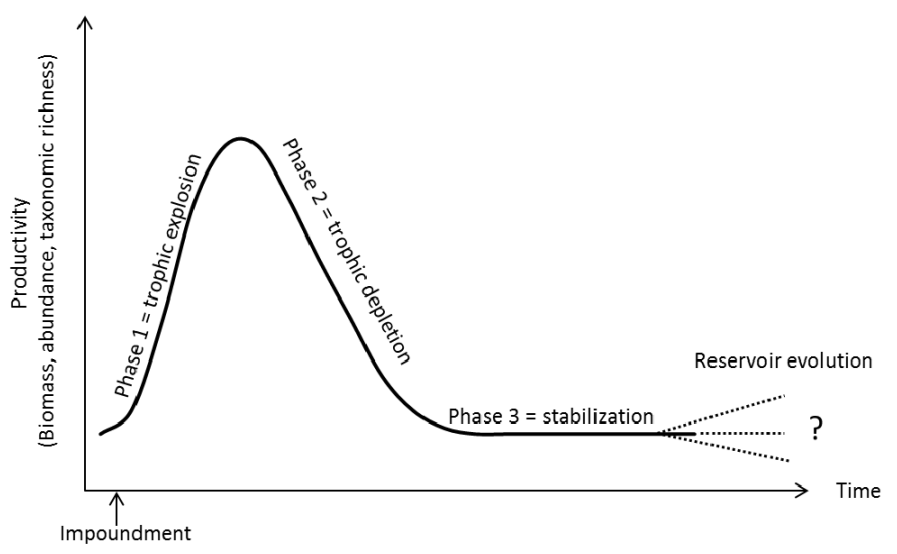

Fig. 1. Expected fish population productivity evolution in the Nam Theun 2 Reservoir according to the time after impoundment (adapted from Balvay, 1985).

Fig. 1. Évolution attendue de la productivité des populations piscicoles du réservoir de Nam Theun 2 en fonction du temps, après inondation (adapté de Balvay, 1985).

population dynamics (Baxter, 1977; Balvay, 1985; Mol et al., 2007). Fish population studies in newly impounded reservoir led to develop a general scheme of the fish dynamic evolution. A succession of three distinct phases is commonly observed with respectively (i) a high fish production (biomass, abundance, and taxonomic richness) linked to the trophic upsurge, followed by (ii) a decline for all parameters and (iii) a state of low variability before reaching a steady-state (Petr, 1978; Kimmel \& Groeger, 1986, Fig. 1).

The Mekong River Basin is known to shelter large fish diversity. It supports the third most diverse fish fauna in the world (Baird \& Flaherty, 2005). The total or expected number of species from the Mekong River Basin was estimated at 1,200 species (Rainboth, 1996). However, this number may be under-estimated (Lévêque et al., 2008) as (i) numerous habitats and remote areas have still not been explored and (ii) numbers of species have not been formally named. In addition, the knowledge on fish biology in most of Asia remains incomplete (Kottelat, 1998). Furthermore, the Mekong is defined as one of the largest inland fisheries areas in the world (Vidthayanon, 2008; Kang et al., 2009) and freshwater fish are a basic food resource for human population in the region. The creation of a reservoir tends to increase locally these fishery activities, especially fish farms.

Because of high biodiversity and economical interest of fish in the Lower Mekong Basin, fish are a focus point of the studies conducted in Southeast Asia reservoirs especially on fisheries (Kolding \& van Zwieten, 2006) and on biodiversity aspects. Whereas mainly of these studies have been conducted in the Mekong mainstream (Kang et al., 2009), scientific fish assessment remains poorly documented for tributaries of the 
Lower Mekong. Therefore, the understanding of the fish population dynamic and evolution in newly impounded reservoirs such as the Nam Theun 2 (NT2) Reservoir (Lao PDR) is a valuable asset for sustainable fisheries management and biodiversity conservation.

The first objective of the study was to assess the evolution of fish population taxonomic richness, abundance, and biomass in the NT2 Reservoir since its impoundment. Conducted over a consecutive period of 6 years, this monitoring gave the opportunity (i) to determine the mid-term of the fish population in this newly impounded reservoir, (ii) to identify the environmental factors driving the fish population (e.g. season, habitat...). In addition, it enabled to improve the local fish biology knowledge through size range analysis of two main species.

\section{METHODS}

\subsection{Sampling strategy}

\subsubsection{Study area}

The NT2 Project is a trans-basin hydropower scheme located in the Mekong Basin, Khammouane Province, central Lao PDR. Its design leads to a diversion of water from the NT2 Reservoir (Nakai Plateau; Nam Theun watershed) to the Xe Bangfai River southwards (Xe Bangfai watershed). On the Nakai Plateau, a Headrace Channel ensures that reservoir water mass can reach the water Intake. Here, waters are conveyed to the Power
House located $360 \mathrm{~m}$ below the Nakai Plateau. Turbinated waters are released into the Regulating Pond followed by a $27 \mathrm{~km}$ long Downstream Channel joining the Xe Bangfai River southwards (Fig. 2). All detailed features of this project (civil works and monitoring programmes) are described in Descloux et al. (same issue).

The impoundment of the reservoir started in April 2008. The Nakai dam (439 $\mathrm{m}$ long and $39 \mathrm{~m}$ high) is situated on the Northwest Nam Theun River and ensures riparian release $\left(2 \mathrm{~m}^{3} \mathrm{~s}^{-1}\right)$ in the Nam Theun River downstream. Commercial operation, supervised by the Nam Theun 2 Power Company (NTPC) started in April 2010. The NT2 Reservoir covers a surface area of 489 $\mathrm{km}^{2}$ area at its full supply level (Fig. 2) and potentially decreases to a minimum of $86 \mathrm{~km}^{2}$ at the end of the dry season. The reservoir is relatively shallow with an average depth of $8 \mathrm{~m}$ (Chanudet et al., 2012). The main tributaries of the reservoir are the Nam Xot, the Nam Theun and the Nam On Rivers. The reservoir flooded almost $70 \%$ of dense to light forest, $23 \%$ of degraded forest, riparian forest and agricultural soils and the last $7 \%$ were composed of water system, swamps and villages (Descloux et al., 2011). The Nam Theun watershed is mainly composed of sandstones and waters are characterized by a low conductivity (10 to $65 \mu \mathrm{S} . \mathrm{cm}^{-1}$, Chanudet et al., same issue). The climate is moist subtropical with a warm-wet (WW) season (June to October), a cool-dry (CD) season (November to February) and a warm-dry (WD) season (March to May). 


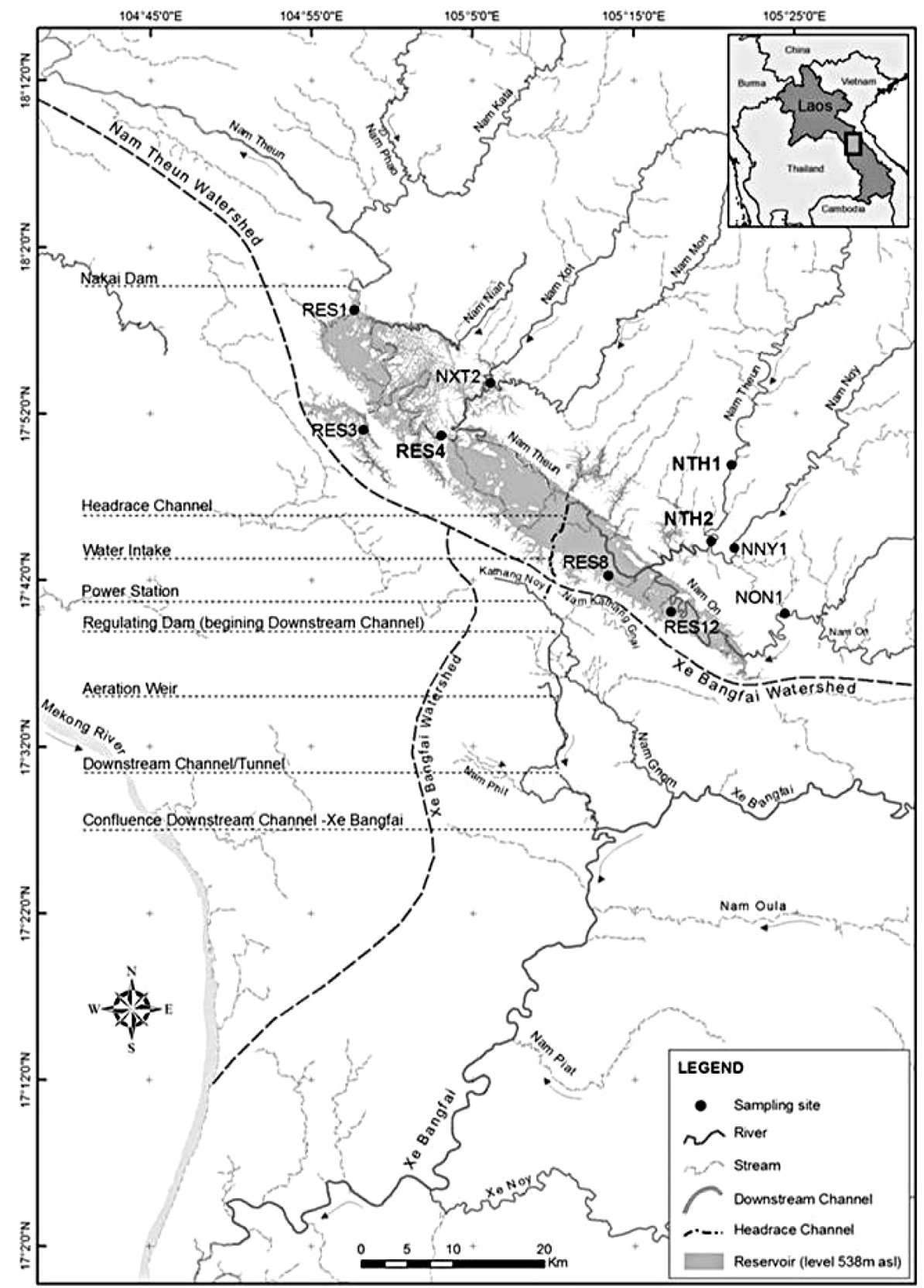

Fig. 2. Fish population monitoring stations. The three permanent stations (monitored since 2008) are represented in bold.

Fig. 2. Stations de suivi des populations de poissons. Les trois stations permanentes (suivies depuis 2008) sont inscrites en gras. 


\subsubsection{Monitoring stations and sampling frequency}

Fish population monitoring started in April 2008 at the NT2 Reservoir closure according to three permanent stations (Fig. 2) on the Nam Theun thalweg.

NTH1, free from the reservoir backwater effect, is the upstream reference station for the Nam Theun River. This station presents the typical features of sub-tropical pristine rivers (Chanudet et al., same issue). NTH2, in the transition area between the river and the reservoir, is under the influence of the reservoir. RES4, in the core area of the reservoir, has been selected to monitor the temporal change of fish population in the new lentic system created by the impoundment (WW-2008). Data at RES4 before impoundment (river system) are available only for WD season 2008.

In 2012, to strengthen the knowledge on fish population, additional stations were monitored to cover a larger panel of habitats within each system: (i) reservoir system (RES1, RES3, RES8, and RES12), (ii) transition system (NXT2 and NON1) and (iii) upstream river system (NNY1) (Fig. 2).

Two campaigns per year were conducted (Fig. 3): (i) at the end of the warm-dry season (from the end of March to early May) and (ii) at the end of the warm-wet season (from the end of September to early November).

\subsubsection{Sampling method}

\section{Fish population monitoring}

Two batteries of 10 surface gillnets $25 \mathrm{~m}$ long by $2 \mathrm{~m}$ height of mesh size
$10,15,20,25,30,35,40,50,60$ and $70 \mathrm{~mm}$ between knots, representing a total fishing surface of $1000 \mathrm{~m}^{2}$, were set overnight at each station (1516 hours). In the reservoir and in transition areas, gillnets were set close to the shore and in habitats previously covered by dense forest, light forest or agricultural soil. In the rivers, gillnets were set close and parallel to the riverbank in areas of low water current. For each station and campaign, gillnets were set by groups of two, three or four nets attached together to respect the same proportion of each habitats (e.g. patch of inundated trees, sandy/gravel area, small streams...).

During each campaign, all collected fish were identified at the species level (Rainboth, 1996; Kottelat, 1998, 2001), measured (standard length in $\mathrm{mm}$ ) and weighted (g).

\section{Environmental parameters}

For each campaign, the dominant habitat was determined for the reservoir and transition areas stations (Tab. I) according to the following definition:

i) Open area = inundated old agricultural soils, scarce under-water architecture mainly composed by shrubs.

ii) Inundated light forest = inundated trees representing a maximum of $20 \%$ of the area. Inundated trees are mainly shrubs mixed with medium size trees.

iii) Inundated medium forest = inundated trees representing a maximum of $40 \%$ of the area. This habitat is mainly composed by medium and large trees and a small number of shrubs. 


\section{Rain (NT2 Reservoir)}
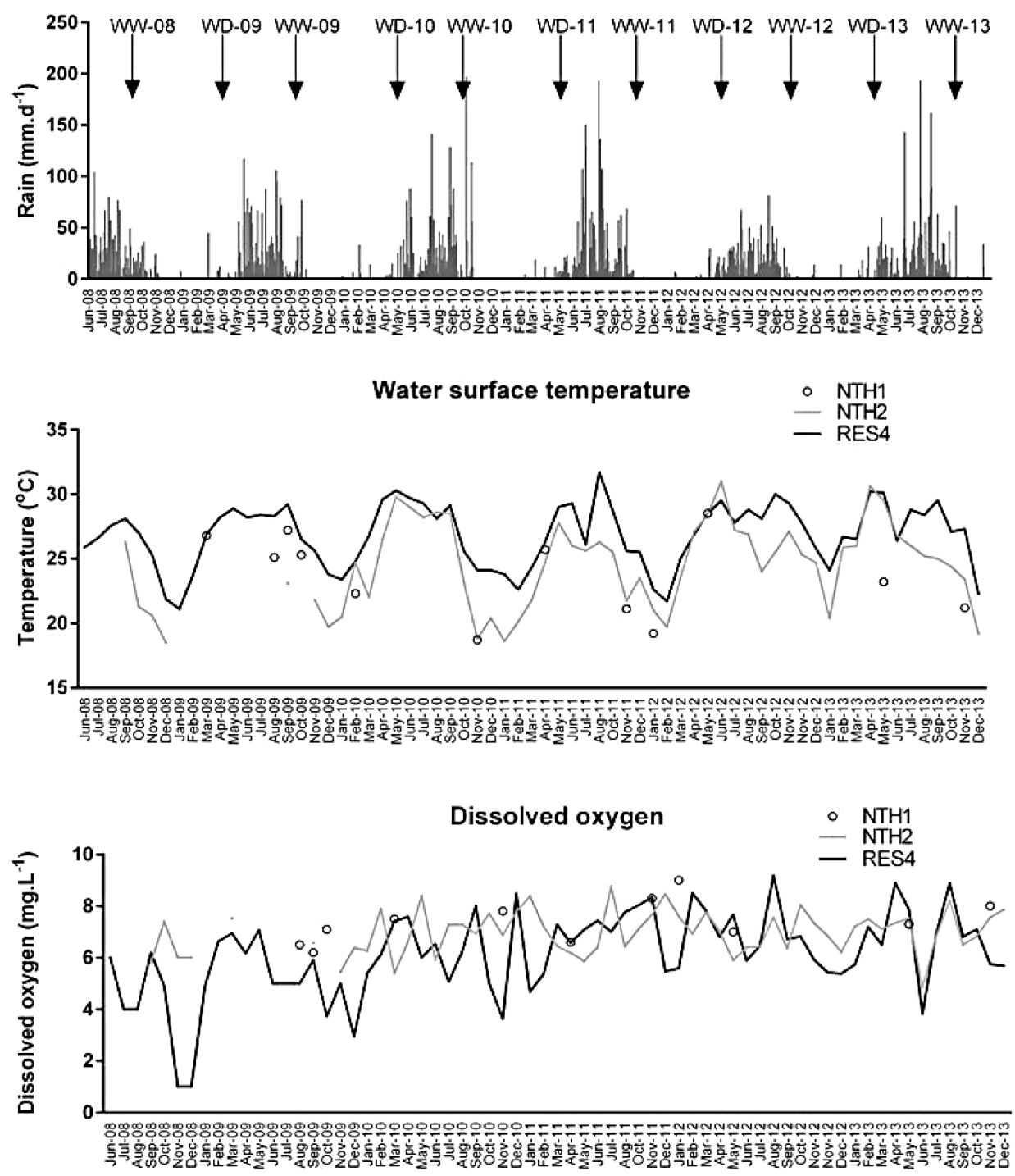

Fig. 3. Rain (Nakai plateau), temperature and dissolved oxygen of surface water for the three permanent stations. Only discrete data are available for NTH1. Arrows indicate the fish population monitoring missions (WD = end of the dry season; $W W=$ end of the wet season).

Fig. 3. Pluie (Plateau de Nakai), température et oxygène dissous des eaux de surface pour les trois stations permanentes. Seulement quelques valeurs sont disponibles pour NTH1. Les flèches indiquent les missions du suivi des populations de poissons (WD = fin de la saison sèche et chaude, $W W=$ fin de la saison humide et chaude). 
Table I. Main characteristic of the stations during fish population monitoring (FSL = full supply level). Tableau I. Principales caractéristiques des stations pendant le suivi des populations de poissons ( $F S L=$ au niveau le plus haut).

\begin{tabular}{|c|c|c|c|c|c|c|c|}
\hline System & Station & \begin{tabular}{|c|} 
Max. depth \\
$(\mathrm{m})$ in the \\
area (FSL)
\end{tabular} & $\begin{array}{c}\text { Water surface } \\
\text { temperature } \\
\left({ }^{\circ} \mathrm{C}\right)\end{array}$ & $\begin{array}{l}\text { Dissolved } \\
\text { oxygen } \\
\left(\mathrm{mg}^{-1} \mathrm{~L}^{-1}\right)\end{array}$ & $\begin{array}{c}\text { Dominant } \\
\text { habitat }\end{array}$ & \begin{tabular}{|l|} 
Fishing \\
activity
\end{tabular} & $\begin{array}{c}\text { Field } \\
\text { observation }\end{array}$ \\
\hline \multirow{2}{*}{ 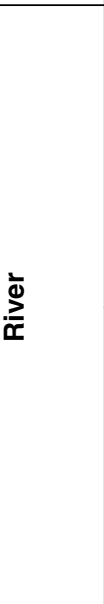 } & NTH1 & 13.7 & $\begin{array}{l}\text { WD [23.2-28.5] } \\
\text { WW [21.2-21.8] }\end{array}$ & $\begin{array}{l}\text { WD [7.3-7.1] } \\
\text { WW [7.4-7.9] }\end{array}$ & $\begin{array}{c}\text { River system } \\
\text { with pool, } \\
\text { surroundedby } \\
\text { riparianforest, } \\
\text { bed } \\
\text { substratesare } \\
\text { mineralblocks } \\
\text { and sand }\end{array}$ & 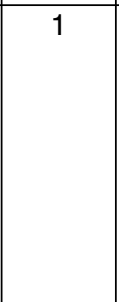 & $\begin{array}{l}\text { Presence of } \\
\text { villages }\end{array}$ \\
\hline & NNY1 & 8 & $\begin{array}{l}\text { WD [28.0-28.4] } \\
\text { WW [22.5-22.8] }\end{array}$ & $\begin{array}{l}\text { WD [6.9-7.1] } \\
\text { WW [8.0-8.3] }\end{array}$ & $\begin{array}{c}\text { River system } \\
\text { with pool, } \\
\text { surroundedby } \\
\text { riparianforest, } \\
\text { bed } \\
\text { substratesare } \\
\text { mineralblocks } \\
\text { and sand }\end{array}$ & 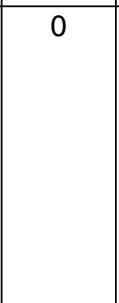 & Far of villages \\
\hline \multirow{3}{*}{ 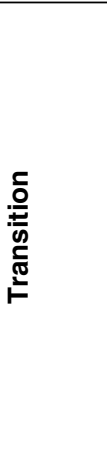 } & NTH2 & 23.2 & \begin{tabular}{|l|} 
WD [30.1-30.6] \\
WW [23.4-27.2]
\end{tabular} & \begin{tabular}{|l|} 
WD [6.7-7.5] \\
WW [7.2-7.4]
\end{tabular} & $\begin{array}{c}\text { Inundated } \\
\text { medium forest }\end{array}$ & 0 & $\begin{array}{c}\text { In the } \\
\text { National } \\
\text { protected } \\
\text { area, far from } \\
\text { villages }\end{array}$ \\
\hline & NXT2 & 14.3 & $\begin{array}{l}\text { WD [28.2-30.9] } \\
\text { WW [27.4-27.8] }\end{array}$ & $\begin{array}{l}\text { WD [5.1-6.8] } \\
\text { WW [7.5-7.7] }\end{array}$ & $\begin{array}{c}\text { Inundated } \\
\text { medium forest }\end{array}$ & 1 & \begin{tabular}{|l|}
$\begin{array}{l}\text { Close to } \\
\text { villages }\end{array}$ \\
\end{tabular} \\
\hline & NON1 & 21 & $\begin{array}{l}\text { WD [29.0-31.4] } \\
\text { WW [23.5-27.4] }\end{array}$ & $\begin{array}{l}\text { WD [7.7-8.2] } \\
\text { WW [5.9-6.9] }\end{array}$ & $\begin{array}{c}\text { Inundated } \\
\text { dense forest }\end{array}$ & 0 & \begin{tabular}{|c|} 
In the \\
National \\
protected \\
area, far from \\
villages
\end{tabular} \\
\hline \multirow{5}{*}{ 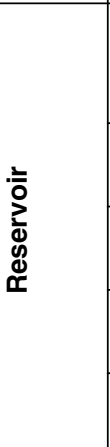 } & RES1 & 37 & \begin{tabular}{|l|} 
WD [28.3-30.6] \\
WW [23.5-26.6]
\end{tabular} & $\begin{array}{l}\text { WD [6.8-7.1] } \\
\text { WW [6.0-7.8] }\end{array}$ & $\begin{array}{l}\text { Inundated } \\
\text { light forest }\end{array}$ & 1 & $\begin{array}{l}\text { Close to dam } \\
\text { site, far from } \\
\text { villages }\end{array}$ \\
\hline & RES3 & 19 & \begin{tabular}{|l|} 
WD [28.8-30.2] \\
WW [26.5-30.3]
\end{tabular} & $\begin{array}{l}\text { WD [6.2-6.4] } \\
\text { WW [4.7-8.0] }\end{array}$ & $\begin{array}{c}\text { Inundated } \\
\text { dense forest }\end{array}$ & 1 & $\begin{array}{c}\text { Far from } \\
\text { villages }\end{array}$ \\
\hline & RES4 & 30 & \begin{tabular}{|l|} 
WD [29.3-30.3] \\
WW [28.1-31.8]
\end{tabular} & \begin{tabular}{|l|} 
WD [7.3-7.6] \\
WW [6.6-7.0]
\end{tabular} & $\begin{array}{c}\text { Inundated } \\
\text { medium forest }\end{array}$ & 2 & $\begin{array}{l}\text { Close to } \\
\text { villages }\end{array}$ \\
\hline & RES8 & 23 & \begin{tabular}{|l|} 
WD [26.6-30.5] \\
WW [26.4-29.7]
\end{tabular} & \begin{tabular}{|l|} 
WD [7.4-7.5] \\
WW [7.1-7.9]
\end{tabular} & Open area & 2 & $\begin{array}{l}\text { Close to } \\
\text { villages }\end{array}$ \\
\hline & RES12 & 18 & \begin{tabular}{|l|}
$W D[30.7-31.5]$ \\
$W W[24.0-26.2]$
\end{tabular} & \begin{tabular}{|l|} 
WD [7.0-7.9] \\
WW [8.1-8.3]
\end{tabular} & Open area & 2 & $\begin{array}{l}\text { Close to } \\
\text { villages }\end{array}$ \\
\hline
\end{tabular}


iv) Inundated dense forest = inundated trees representing at least $50 \%$ of the area. Trees communities are mainly composed by medium and large trees.

v) Riparian forest.

Furthermore, an estimation of fishing activities over the study was estimated and encoded as "0" for no fishing activities, " 1 " for scarce fishing activities (few nets observed), and "2" for significant fishing activities (amount of nets observed in the area more than 6 units) (Tab. I). Complementary descriptions of surroundings were added such as the presence of village or location of the station in the National Protected area (Tab. I).

The surface water dissolved oxygen and temperature were measured in situ with a multi-parameter probe (Hydrolab Quanta). Rain was obtained from the Hydrology Division of NTPC. Values for the three permanent stations (NTH1, NTH2 and RES4) are presented in Figure 3. Ranges of values for all stations (temperature and dissolved oxygen) are presented in Table I.

\subsection{Data analysis}

\subsubsection{Fish population temporal} evolution for the three permanent stations (NTH1, NTH2, and RES4)

Biological metrics e.g. total biomass $(\mathrm{kg})$, total abundance (number of individuals) and taxonomic richness (number of species) were used to describe the fish population temporal evolution for each station.

Median of the size of the catch $(\mathrm{mm}$ \pm 1 st and 3rd quartile) was calculated for each station and season to assess the general evolution of the fish population. Kruskal-Wallis non-parametric test, completed by a Dunn's multiple comparison test was carried out to assess the significance among medians.

Finally, the size class frequencies for the cyprinid species Hampala macrolepidota and Poropuntius carinatus, which were continuously caught since impoundment, were analysed to strengthen the knowledge on the biology of these species and potentially identify an influence of the impoundment. The size class frequency was plotted for both species as the number of individuals for each $10 \mathrm{~mm}$ class.

\subsubsection{Relationship among aquatic systems, habitat and fish}

A principal component analysis was performed under XLSTAT software in view to identify environmental factors (e.g. habitat, fishing pressure, season, temperature and dissolved oxygen) influencing the biomass $(\mathrm{kg})$ and number of species (TR) for all the stations monitored in the reservoir, transition areas and rivers upstream. This analysis was performed for the years 2012 and 2013 representing the beginning of the steady-state of the fish populations. A Pearson ( $n$ ) correlation matrix test was realized to see the significance of correlation between each variable.

Hierarchical ascendant classifications (HAC) were performed with XLSTAT software to characterized fish population in terms of biomass and abundance of the different species according to each main habitat. A first 
HAC was carried out using a " station $x$ biomass 2012-2013 " matrix and a second HAC using a " station $x$ abundance of the species ' $i$ ' in 2012 and 2013 " with data transformed in log $(x+1)$. Dissimilarity between stations was calculated based on Euclidian distance, method of Ward including 4 classes according to the results of the PCA and with a truncation level at 0.05 .

\section{RESULTS}

\subsection{Fish population temporal evolution}

\subsubsection{Population composition}

A total of 33 species were identified by the surface gillnets monitoring in the reservoir (RES4), Nam Theun upstream (NTH1) and the transition area (NTH2) between 2008 and 2013. These species belong to 10 families. Fish populations were dominated by the Cyprinidae family with a total of 24 species (Tab. II, Appendix 1). Some species were found in these stations since the beginning of the monitoring e.g. Hampala macrolepidota (defined as ubiquitous), and two small size cyprinids Puntius brevis and Rasbora paviei. These two last species showed a high abundance after the impoundment (WW-08 and WD-09, Tab. II). At this period, riverine species were still caught at the 3 stations (e.g. Danio fangfangae, Hypsibarbus spp., Mystacoleucus marginatus, Poropuntius carinatus, or Rhodeus laoensis).

Species compositions were similar among stations at the beginning of the monitoring (2008-2009). Afterward, a clear differentiation between reservoir population and river/transition population occurred, as strict riverine species rarefied from the reservoir (e.g. Poropuntius carinatus or Hypsibarbus spp.) Surprisingly, Cyclocheilichthys spp., species known to persist after an impoundment (Rainboth, 1996), was mainly recorded in the Nam Theun River and the transition area but have been rarefied in the reservoir since the end of 2009 (Tab. II). The fish population of the reservoir (RES4) was dominated by Hampala macrolepidota. In 2013, new species have been recorded in the Nam Theun 2 area e.g. Parambassis siamensis (Chandidae) observed in all stations (NTH1, NTH2 and RES4).

Populations from Nam Theun upstream (NTH1) and the transition area (NTH2) were different from those of the reservoir. These populations were mainly composed of cyprinids Cyclocheilichthys spp., Hypsibarbus spp., Mystacoleucus marginatus, and Poropuntius carinatus that are known to live in stream/river and not to persist after an impoundment (Rainboth, 1996). Furthermore, some species appeared to be more frequently caught in specific areas. For example, Cirrhinus molitorella was more frequent in transition areas, while Mastacembellus armatus was more frequent in the river upstream (NTH1).

Four years after impoundment, some endemic species of the Nam Theun River, described by Kottelat (1998) were still observed e.g. Luciocyprinus striolatus at NTH2 and Bangana elegans at NTH1 whereas some other species were not caught anymore 


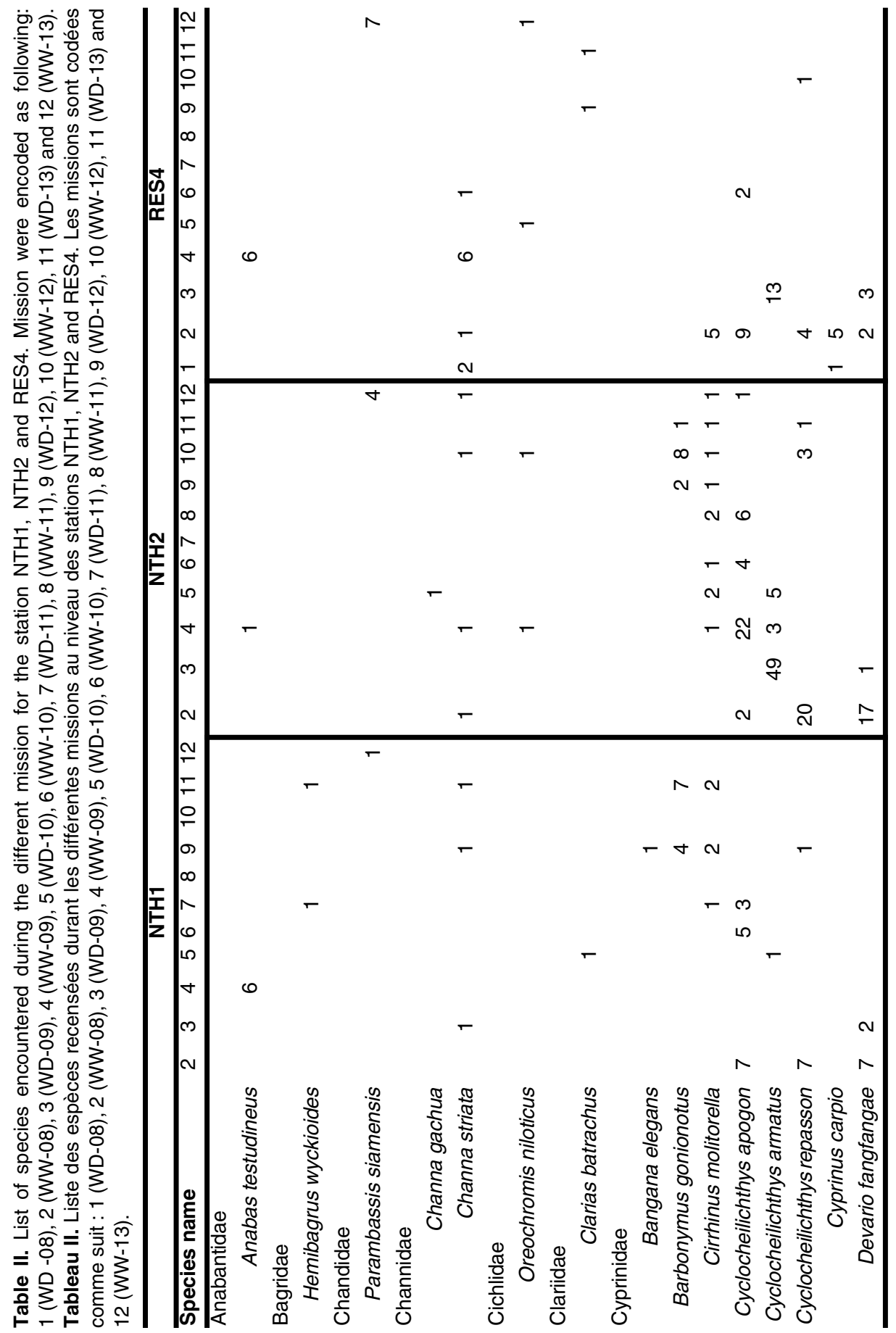


M. Cottet et al.

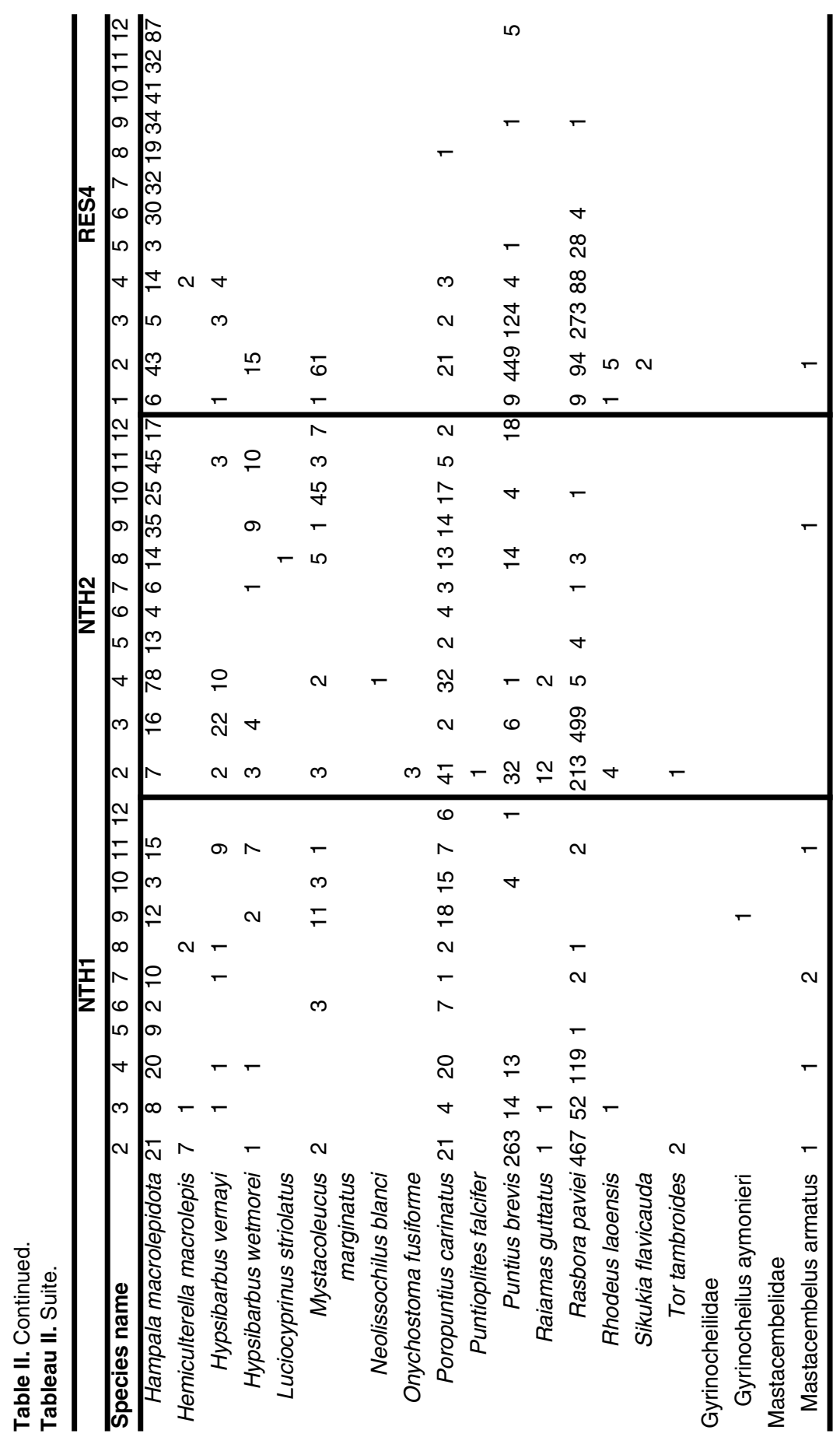


River upstream (NTH1)
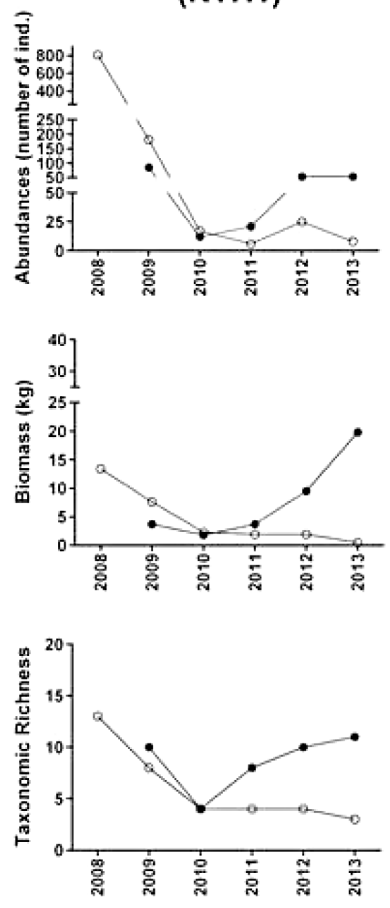

Transition area

(NTH2)
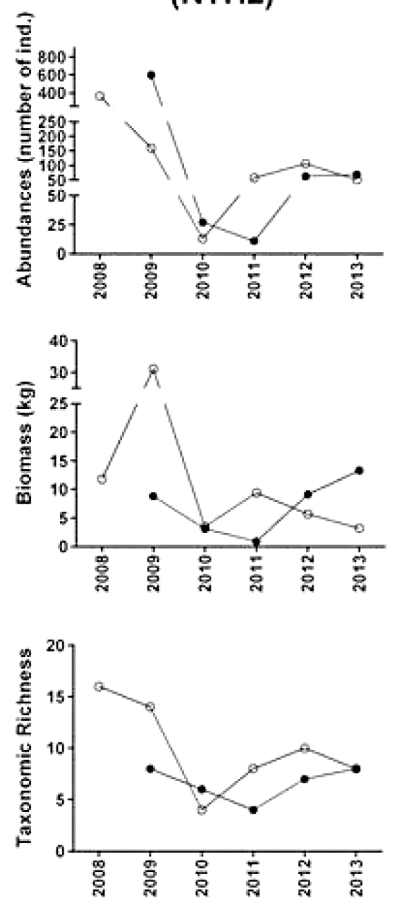

Reservoir

(RES4)
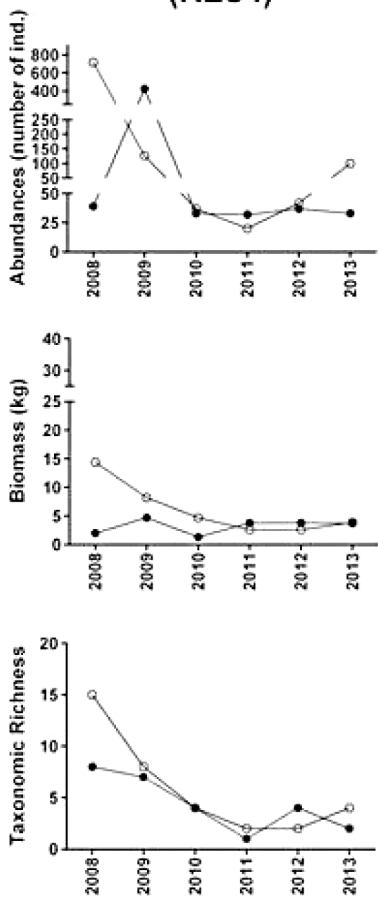

Fig. 4. Fish biomass (kg), abundance (number of individuals) and taxonomic richness (number of species) for the NTH1, NTH2, and RES4 at the end of the warm-dry season (WD) (black circles) and at the end of the warm-wet season (WW) (empty circles).

Fig. 4. Biomasse (kg), abondance (nombre d'individus) et richesse taxonomique (nombre d'espèces) des peuplements piscicoles à NTH1, NTH2 et RES4 à la fin de la saison sèche (WD) (cercles noirs) et à la fin de la saison des pluies (WW) (cercles vides).

at NTH1 and NTH2 after 2009 (e.g. Danio fangfangae, Raiamas guttatus, Rhodeus laoensis, or Tor tambroides). New species were present at NTH1 and NTH2: Barbonymus gonionotus is caught since 2012 and Parambassis siamensis since 2013 (Tab. II).

\subsubsection{Biological metrics}

In the Nam Theun upstream (NTH1), fish population showed a decline over the 2 years after the impoundment (2008-2010) in terms of biomass, abundance and taxonomic richness for both WW and WD seasons (Fig. 4). The biomass showed a strong decline especially among the WW seasons with $13 \mathrm{~kg}$ (WW-08) to $2 \mathrm{~kg}$ (WW-10) (Fig. 4). Abundances followed the same trends with a diminution of $98 \%$ of the total number of individuals between the WW08 and the WW-10. The taxonomic richness showed a decline with values almost 3.5 times lower in WW-10 (4 species) compared to the WW-08 (14 species). 
Since 2011, the biological metrics tended to stabilized during the WW season. As observed for the WW season, biological metrics of the WD seasons declined until 2010 especially for the abundances (85 ind. and 12 ind. for WD-09 and WD-10 respectively) and taxonomic richness (10 species and 4 species for WD-09 and WD-10 respectively; Fig. 4). Since 2010, biological metrics increased during the WD seasons. For instance, between the WD-10 and the WD-13, abundances increased from 12 ind to 53 ind., biomass increased from $1.8 \mathrm{~kg}$ to $19.8 \mathrm{~kg}$, and taxonomic richness increased from 4 species to 11 species.

In the transition area (NTH2), biological metrics declined after the impoundment for the WW and WD seasons until 2010 and 2011 respectively except a peak of biomass observed during the WW-09 (Fig. 4). Since 2011, all biological metrics increased during the WD seasons (abundance: WD-11=11 ind. and WD-13=69 ind.; biomass: WD-11= $0.9 \mathrm{~kg}$ and $W D-13=13.3 \mathrm{~kg}$; taxonomic richness: WD-11 $=4$ species and WD-13= 8 species). In the wet seasons, values increased for abundance and taxonomic richness since the WW-10 (13 ind., 4 species) until the WW-13 (51 ind., 8 species). Biomass seemed to maintain around $3.5 \mathrm{~kg}$ except a limited peak during the WW- 11 .

In the reservoir station (RES4) and during the dry seasons, an increase occurred for abundances and in a less extent for biomass just after the impoundment (WD-09) (Fig. 4) with biomass 2.5-fold higher and abundance 11-fold higher than in the former river system (WD-08). Then, values declined during the following WD-10 for the biomass and abundance. Afterwards, both abundance and biomass maintained in a same range of values for the WD seasons campaigns (Fig. 4). The taxonomic richness declined from the WD-08 (8 species) to 2013 (2 species; with a drop in the WD-11 at 1 species). Biological metrics during the WW seasons showed a constant decline from WW-08 (abundance: 717 ind., biomass: $14.4 \mathrm{~kg}$, and taxonomic richness: 15 species) until the WW-11 (abundance: 20 ind., biomass: $2.6 \mathrm{~kg}$, and taxonomic richness: 2 species). Since then, biomass remained to this constant level around 2.5 to $3 \mathrm{~kg}$ and a taxonomic richness around 2 species (except during the WW-13; 4 species). These values of biomass and taxonomic richness during the WW seasons since 2011 are in the same range than those observed during the WD seasons (Fig. 4). Finally, abundance started to increase after 2011 during the WW season missions and has reached values higher than those observed in the river before the impoundment (WW-13= 100 ind. vs. WD-08=39 ind.).

\subsubsection{Fish size of the catch}

The median of the fish size of the total catch at NTH1 among the WD seasons increased significantly with time (Kruskal-Wallis test, $p<0.05$ ) from $74 \mathrm{~mm}$ (WD-09) to $236 \mathrm{~mm}$ (WD-13,) (Fig. 5). To a lesser extent, this trend was also noticed during the WW seasons (WW-08: $68 \mathrm{~mm}$ vs. WW-13: $145 \mathrm{~mm}$ ). Finally, highest median of size catch were observed at the end of the WD seasons.

The same trend was observed at NTH2 (transition area) during the WD 


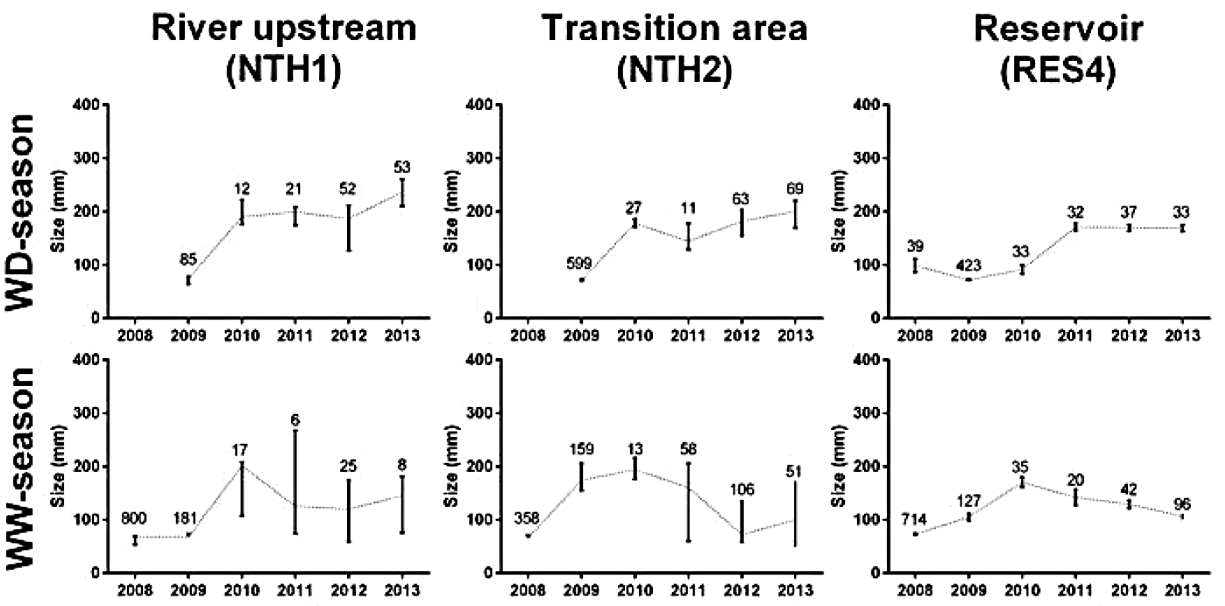

Fig. 5. Median of the fish size of the catch $(\mathrm{mm} \pm 1$ st and 3rd quartile, number of individuals above each point) at the NTH1, NTH2, and RES4 at the end of the warm-dry season (WD) and at the end of the warm-wet season (WW).

Fig. 5. Médiane de la taille du poisson par prise $\left(\mathrm{mm} \pm 1^{\mathrm{er}}\right.$ et $3^{\mathrm{ème}}$ quartile, nombre d'individus au-dessus de chaque point) à NTH1, NTH2 et RES4 à la fin de la saison sèche (WD) et à la fin de la saison des pluies (WW).

season with a median of fish size of the total catch increasing significantly from the WD-09 $(71 \mathrm{~mm})$ and the WD-13 (200 mm; Kruskal-Wallis test, $p<0.05$ ). Highest median of size catch were observed during the WW seasons 2009, 2010 and 2011. These medians declined and reached values during the WW-12 and WW-13 comparable to those observed in the WW-08.

The median size in the reservoir station (RES4) appeared to be stable from WD-08 (pre-impoundment mission, $60 \mathrm{~mm})$ to the WD-10 $(76 \mathrm{~mm})$. Then, values increased significantly (KruskalWallis test, $p<0.05)$ during the WD-11 $(159 \mathrm{~mm})$ and remained stable until the WD-13 (Fig. 5). Median of the size catch remained in a same range for the WW seasons. Only median of the WW10 were significantly higher than those observed during the WW-08, WW-09 and WW-13 which are the lowest observed values (Fig. 5). Nevertheless, the difference between the two seasons remained low and less marked than those observed in the river upstream (NTH1).

For all stations, small individuals dominated populations in 2008 and 2009 (Fig. 5, Tab. II). Afterwards, medium individuals dominated the population until the end of the presented monitoring. Furthermore, an increase of the abundance of large individuals is noticed in the Nam Theun upstream since 2011 (starting from 3 in 2008 and reaching 22 in 2013). The transition area and the reservoir stations showed a relatively low catch of large individuals (maximum of 6 individuals in 2012 at $\mathrm{NTH2}$ ). 
3.1.4 Size frequency of both species $H$. macrolepidota and $P$. carinatus

Previous species composition analysis underlined the presence of ubiquitous species e.g. H. macrolepidota for all habitat and the species $P$. carinatus mainly for the transition area (NTH2) and the river upstream (NTH1) (Tab. II).

The size distribution of $H$. macrolepidota (Fig. 6) did not show a change in the population structure at NTH1, NTH2 and RES4. The smallest individuals (new cohort) were mainly collected at the end of the WW seasons in WW-08, WW-11 and WW-12 at NTH2, WW-08 at NTH1, and especially WW-11, WW-12 and WW-13 at RES4. Since 2011, the number of young individuals caught at the end of the wet season increased at RES4. The size frequency spectra remained stable during the WD seasons for all stations. At NTH2, cohort observed during the dry seasons WD-10 and WD-11 was observed during the following wet seasons WW-10 and WW-11, and then disappeared from the catch the following year. Large individuals were present at NTH2 during the WW seasons 2009 mainly, which should correspond to the cohort observed during the previous WD season. However, 2012 and 2013 showed a decline of the cohort registered during the WD season. In the reservoir, some large individual were found during the WD seasons.

Regarding $P$. carinatus, size distribution spectra did not show a clear change for at NTH1 and NTH2 (Fig. 7). Young individuals (size $<10 \mathrm{~cm}$ ) could be identified at the end of the WW season especially at NTH1 and were generally found in the catch the following
WD season. Furthermore, an increase of the frequency of large individual appeared at NTH1 and NTH2 until 2013 during the WD seasons.

\subsection{Relation between aquatic systems, habitat and fish}

\subsubsection{Environmental factors influencing fish population}

The two first axis of the principal component analysis represent $65.1 \%$ of the total inertia (Fig. 8). Taxonomic richness (TR) and biomass are positively correlated to the habitat (axis 1, $\mathrm{n}=0.47$ and $\mathrm{n}=0.37$ respectively, significance level alpha=0.05) and negatively correlated to the fishing activity in the area $(n=-0.55$ and $n=-0.38$ respectively). Then, these environmental parameters are identified as the main drivers of the fish population among all parameters tested in this study. Rivers and transitions areas are separated from the reservoir stations along the axis 1 . In the reservoir, lowest biomasses $(\mathrm{kg})$ were associated with flooded light forest/agricultural soil habitats (RES8 and RES12) especially in 2012 (Tab. III). This low biomass corresponded to a lower abundance of fish in these both stations. Reservoir stations associated to the former dense/ medium forest tend to have higher biomass and abundance averages (RES1, RES4, and RES3; Tab. III). The most productive system appeared to be the transition areas (e.g. NTH2, NON1), which combined flooded dense forest and river influences according to the seasons. River systems showed high biomass especially in 2013 (NTH1 and NNY1, Tab. III). The PCA underlined 

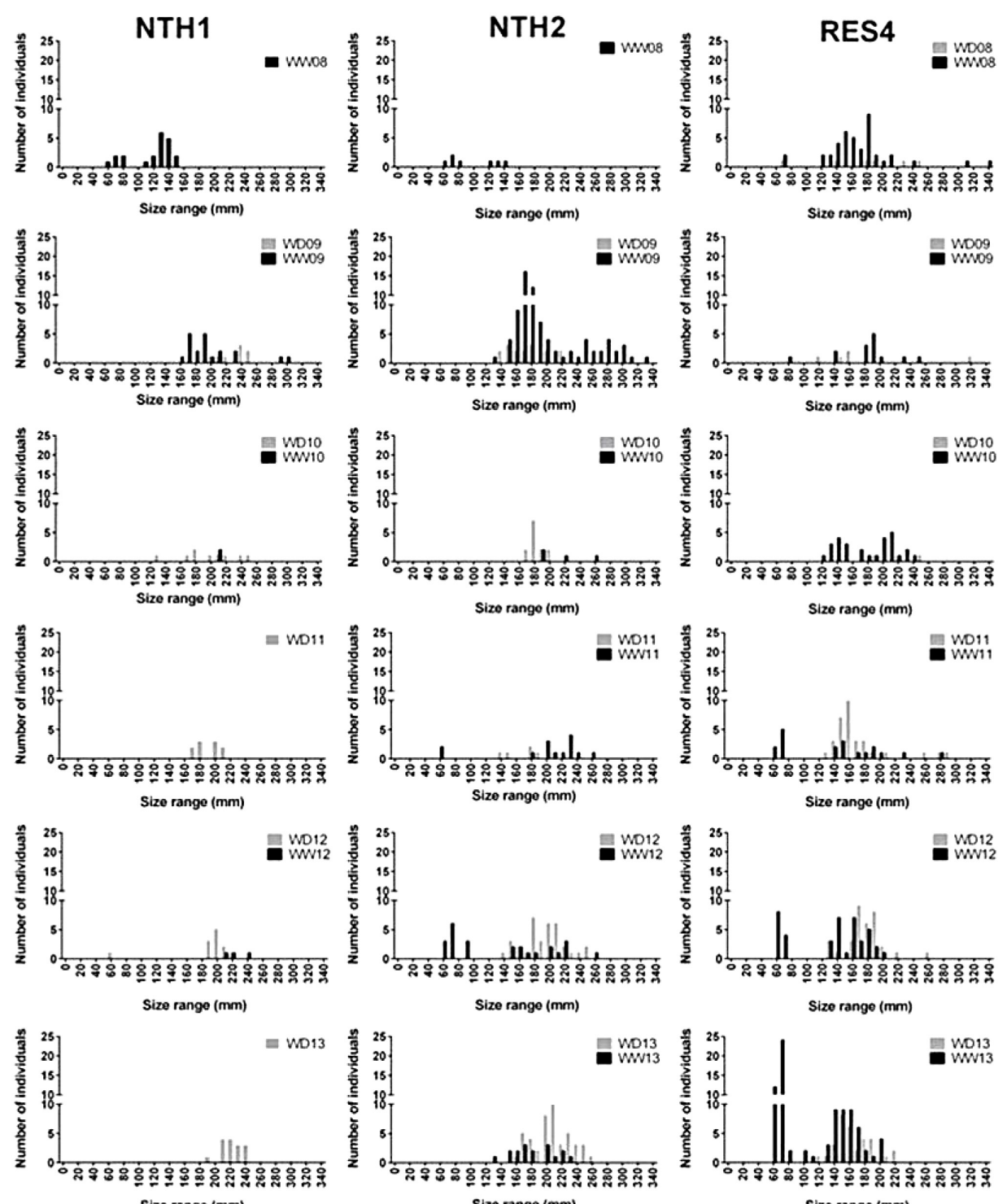

Fig. 6. Size frequency $(\mathrm{mm})$ of Hampala macrolepidota population at NTH1, NTH2, and RES4 at the end of the warm-dry season (WD) and at the end of the warm-wet season (WW).

Fig. 6. Fréquence de taille $(\mathrm{mm})$ des populations d'Hampala macrolepidota à NTH1, NTH2 et RES4 à la fin de la saison sèche (WD) et à la fin de la saison des pluies (WW). 

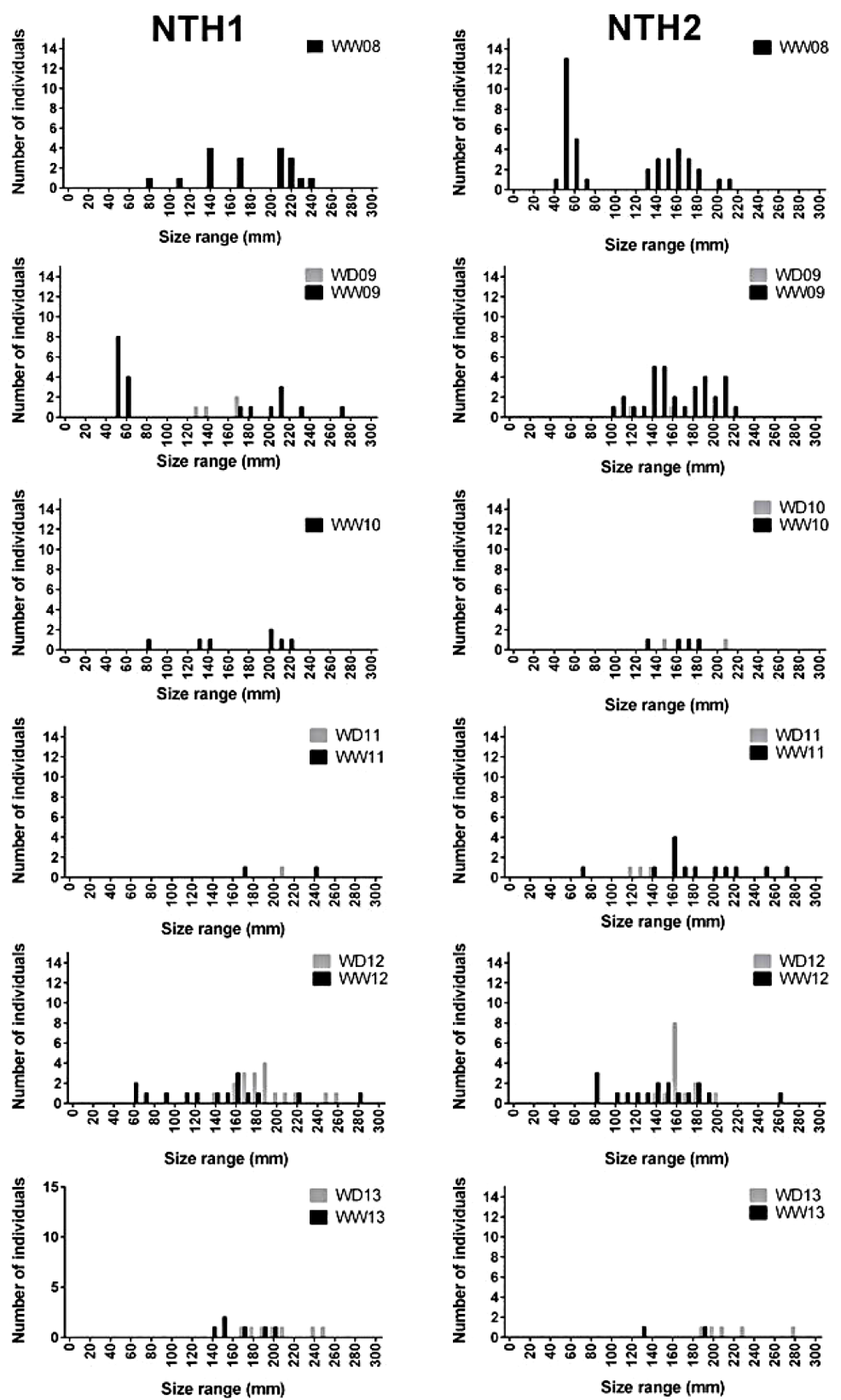

Fig. 7. Size frequency $(\mathrm{mm})$ of Poropuntius carinatus population at NTH1and NTH2 at the end of the warm-dry season (WD) and at the end of the warm-wet season (WW).

Fig. 7. Fréquence de taille $(\mathrm{mm})$ des populations de Poropuntius carinatus à NTH1 et NTH2 à la fin de la saison sèche (WD) et à la fin de la saison des pluies (WW). 


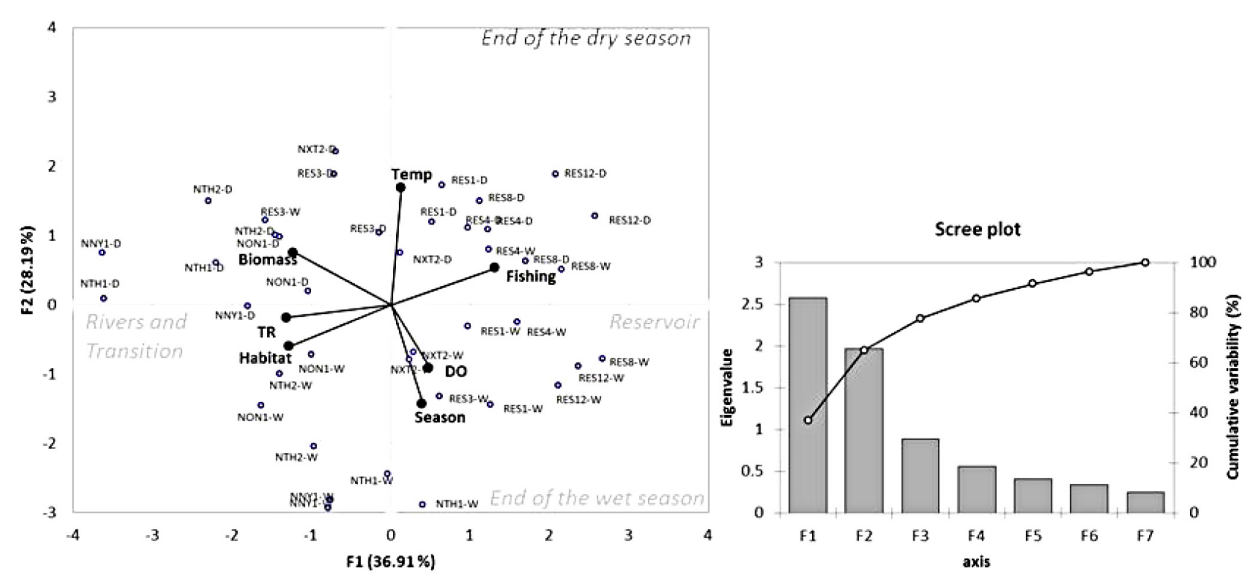

Fig. 8. Principal component analysis, biplot graphic for the mean values of six variables measured at the different station in 2012-2013 with associated eigenvalues histogram. Abbreviation: TR= cumulated taxonomic richness.

Fig. 8. Analyse en composantes principales, graphique biplot des valeurs moyennes de six variables mesurées au niveau des différentes stations en 2012-2013, associes à l'histogramme des valeurs propres. Abréviation : TR = richesse taxonomique cumulée.

that a transition area with structured habitat could lose this productivity potentiality if fishing pressure exists (e.g. NXT2; Fig. 8).

Biomass appeared to be negatively correlated to the season (axis 2, $\mathrm{n}=-0.44$ ). Then, the season appeared to be also an environmental parameter influencing fish population. Previous results for the years 2012-2013 showed that biomass were higher during the WD season (Fig. 4). This is explained by the presence larger individuals of some species (Fig. 6 and Fig. 7) whereas small individuals occurred more frequently during the WW (new cohort, young individuals).

\subsubsection{Rank of biomass and species abundances according to the station}

The HAC (Fig. 9a and Fig. 9b) confirmed this first observation on the most productive system (PCA analysis). This analysis differentiated three groups of stations according to the fish biomass (Fig. 9a). The first group was the Nam Theun system including the station upstream NTH1 and the NNY1 close to the transition area NTH2. The second group was composed by the reservoir (RES4, RES8 and RES12) and transition area (NXT2) with dense/medium forest close to villages (RES4, NXT2) and agricultural soils also close to villages (RES8, RES12). The third group was composed by reservoir (dense forest, RES1 and RES3) and transition area (dense forest, NON1) situated far from villages. The total number of species recorded over 2012-2013 indicated a higher taxonomic richness in the Nam Theun system for both river and transition area (Tab. III). Transition areas (NXT2, NON1, and NTH2) appeared to have, in general, a higher 
Table III. Fish population mean biomass and abundance (standard deviation) in 2012 ar 2013 and total taxonomic richness (TR) cumulated in 2012-2013 for the different stations । the monitoring. Permanent stations are in bold.

Tableau III. Biomasse et abondances moyennes (écart-type) en 2012 et 2013 et richess taxonomique totale (TR) cumulée en 2012-2013 des peuplements piscicoles pour le différentes stations du suivi. Les stations permanentes sont en gras.

\begin{tabular}{|c|c|c|c|c|}
\hline System & Station & $\begin{array}{l}\text { Mean biomass } \\
(\mathbf{k g})\end{array}$ & $\begin{array}{l}\text { Mean abundance } \\
\text { (ind.) }\end{array}$ & $\begin{array}{c}\text { Cumulated taxonomic } \\
\text { richness }\end{array}$ \\
\hline \multirow{2}{*}{$\sum_{\bar{x}}^{\grave{\Phi}}$} & NTH1 & $\begin{array}{c}2012=5.7(5.4) \\
2013=10.5(13.7)\end{array}$ & $\begin{array}{l}2012=39(20) \\
2013=31(33)\end{array}$ & 17 species \\
\hline & NNY1 & $\begin{array}{l}2012=3.6(1.7) \\
2013=8.0(9.0)\end{array}$ & $\begin{array}{c}2012=22(2) \\
2013=51(18)\end{array}$ & 14 species \\
\hline \multirow{3}{*}{ 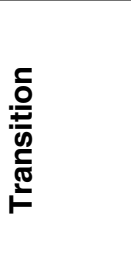 } & NTH2 & $\begin{array}{l}2012=7.4(2.4) \\
2013=8.2(7.1)\end{array}$ & $\begin{array}{l}2012=85(30) \\
2013=61(12)\end{array}$ & 17 species \\
\hline & NXT2 & $\begin{array}{l}2012=4.1(0.7) \\
2013=5.9(0.4)\end{array}$ & $\begin{array}{c}2012=48(16) \\
2013=53(8)\end{array}$ & 12 species \\
\hline & NON1 & $\begin{array}{l}2012=7.8(0.5) \\
2013=6.8(3.2)\end{array}$ & $\begin{array}{c}2012=55(17) \\
2013=47(2)\end{array}$ & 11 species \\
\hline \multirow{5}{*}{ 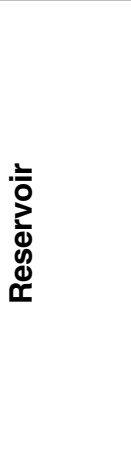 } & RES1 & $\begin{array}{l}2012=6.8(2.3) \\
2013=4.3(3.8)\end{array}$ & $\begin{array}{c}2012=50(2) \\
2013=44(25)\end{array}$ & 3 species \\
\hline & RES3 & $\begin{array}{l}2012=7.8(5.2) \\
2013=7.3(3.1)\end{array}$ & $\begin{array}{l}2012=70(37) \\
2013=88(40)\end{array}$ & 8 species \\
\hline & RES4 & $\begin{array}{l}2012=3.2(0.8) \\
2013=5.6(2.5)\end{array}$ & $\begin{array}{c}2012=40(4) \\
2013=44(16)\end{array}$ & 8 species \\
\hline & RES8 & $\begin{array}{l}2012=2.2(2.0) \\
2013=3.5(1.6)\end{array}$ & $\begin{array}{c}2012=20(11) \\
2013=34(5)\end{array}$ & 7 species \\
\hline & RES12 & $\begin{array}{l}2012=1.9(1.2) \\
2013=3.2(1.3)\end{array}$ & $\begin{array}{l}2012=22(11) \\
2013=39(12)\end{array}$ & 5 species \\
\hline
\end{tabular}

taxonomic richness compared to reservoir stations (around 13 species vs. 6 species). The reservoir station RES1 showed the lowest taxonomic richness with only 3 species identified in 20122013. The HAC separated the stations in 3 groups according to the species composition (Fig. 9b). For all groups, Hampala macrolepidota appeared to be a central object of the analysis, confirming its ubiquitous character. The first group included all reservoir stations. Inside this first group, RES8 and RES12 (light forest/agricultural soil) were separated from RES1 and RES4 (dense forest, near human activities) and RES3 (dense forest, remote area). The species Oreochromis niloticus contributed to the difference with other groups as well as the species the Parambassis siamensis (newly found in the reservoir) registered in all reservoir 

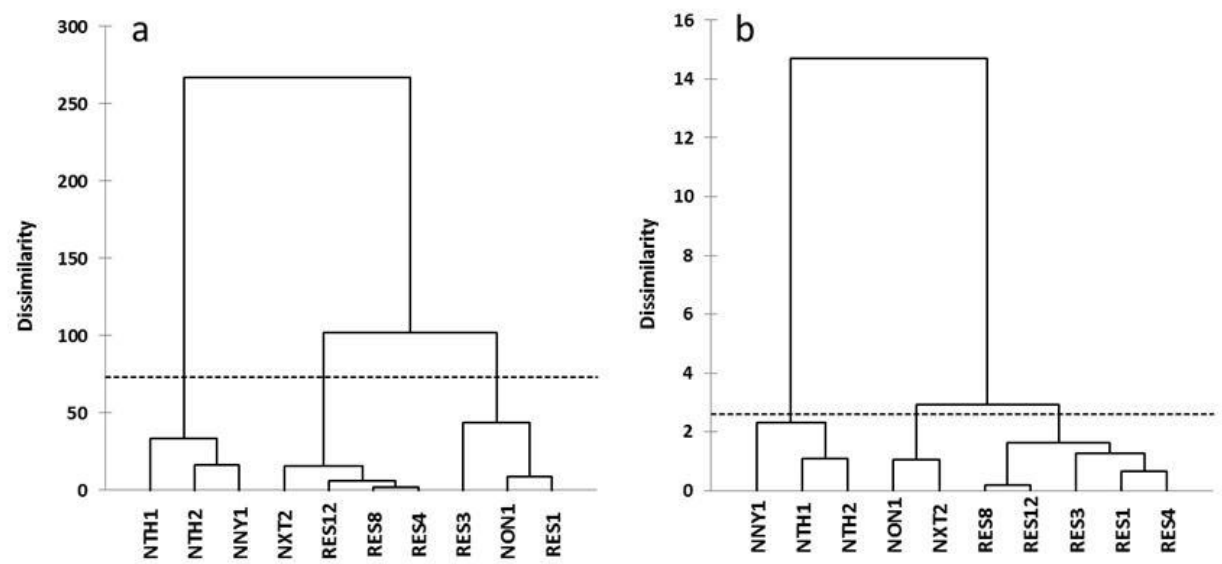

Fig. 9. Hierarchical Ascendant Classifications of the stations based on Euclidian distance (method of Ward) based on biomass (a) and species abundances (b).

Fig. 9. Classification ascendant hiérarchique des stations basée sur la distance euclidienne (méthode de Ward) basée sur les biomasses (a) et l'abondance des espèces (b).

stations during the last mission of WW-13. The second group is composed by the Nam Theun area stations, which are respectively NNY1, and a sub-group NTH1 and NTH2. This second group was characterised by the cyprinids Barbonymus gonionotus, Hypsibarbus spp., Mystacoleucus marginatus, Poropuntius carinatus, and Cirrhinus molitorella. This group also appeared to be separated from the other according to the PCA results (Fig. 8). Finally, the third group included the transition areas of reservoir tributaries NXT2 and NON1. The species Cychlocheilichthys spp., Puntius brevis, Poropuntius carinatus, and Rasbora paviei induced the dissimilarity between this third group and the previous ones.

\section{DISCUSSION}

\subsection{Fish population dynamic in the reservoir, transition area and river}

The monitoring of the permanent reservoir station (RES4) showed the presence of resident fish population, dominated by one Cyprinid: Hampala macrolepidota, which could spend its all life cycle within the reservoir (Poulsen et al., 2004), with reproduction on littoral zone (e.g. swamps).

The fish population evolution in the reservoir was expected to follow 3 distinct phases (Fig. 1). The first phase occurred immediately after the impoundment (2008) and was defined as a high production of fish population corresponding to the trophic upsurge. 
Such biological high productivity after impoundment is documented worldwide (Baxter, 1977; Kubečka, 1993; Crivelli et al., 1995; de Mérona, 2002; Okada et al., 2005). It is explained by (i) an increase in nutrients availability coming from the flooded organic matter degradation (Chanudet et al., same issue) and (ii) a sudden expansion of spawning areas (flooded terrestrial vegetation). During this period, a proliferation of some species, mainly small species, appeared, leading to an increase of abundances in 2009. These species belonged to cyprinids and were dominated by Rasbora paviei, Puntius brevis and Mystacoleucus marginatus. Their temporary proliferation (abundance) was the result of their high physiological tolerance and behavioural plasticity (Okada et al., 2005) and their high growth rate. They took advantage of this new environment defined by a high plankton production related to nutrients availability (Martinet et al., same issue). The mixture of local riverine assemblages (Agostinho et al., 2008) from the tributaries (Nam Theun, Nam Xot or Nam On) explained the highest taxonomic richness in the reservoir during this first phase. Some examples of these riverine species were found just after the impoundment as Devario fangfangae, Hypsibarbus spp. or Poropuntius carinatus.

The second phase (2009 to mid2010) showed an abrupt and continuous decline of biomass, abundance and taxonomic richness in the reservoir. This expected drop could be related to the depletion in nutrient availability with a shift of reservoir trophic status from meso-eutrophia (initial trophic upsurge) to a meso-oligotrophia
(Petr, 1978; Martinet et al., same issue). Kimmel \& Groeger (1986) listed causes linked to the depletion of biological production (including fish). In addition to the nutrient depletion, they identified (i) the decline of biologically labile organic detritus (ii) the end of the lacustrine environment expansion (habitat quantity) and (iii) decline of favourable habitat (habitat quality). In the case of the NT2 Reservoir, this phase of biological production depletion occurred rapidly after the impoundment (around one year) compared to several years as generally observed in temperate and tropical regions (Baxter, 1977; Travade et al., 1985; Williams et al., 1998). The disappearance of the strict riverine species in the catch due to their non-adaptation in the lentic system conditions contributed to the loss of biodiversity in the reservoir itself. The origin of this non-adaptation was related to different causes linked either to the new environment (e.g. creation of pelagic zone, reduction of current), to the food resource, or to species requirement for reproduction (e.g. suitable habitat and hydrology condition). For example, an overview was carried out by Zhong \& Power (1996) on environmental impacts of hydroelectric projects on fish resources in China. It underlined the possible impact on fish species reproducing with surface drifting eggs. When entering into the reservoir, eggs sank and were unable to continue their development (Han River and the Danjiangkou Reservoir). Colonization of the pelagic zone occurs if riverine species are pre-adapted for the lacustrine condition. Fernando \& Holčík (1991) noticed for example that the Clupeidae family are known to establish and could 
significantly participate to the fish catch in the Ubolratana Reservoir (Thailand). This family did not occur in the Nam Theun Reservoir and only the Cyprinidae $H$. macrolepidota seemed to follow the comparable colonization scheme of Clupeids. Surprisingly, some species known to proliferate in reservoir showed a constant decline in abundance (e.g. Cychlocheilichthys spp. or $P$. brevis) during this second phase. This observation underlined the nonadaptation of these species in the Nam Theun 2 Reservoir. The decrease in the productivity of the reservoir (food resource) or the unsuccessful reproduction in the new environment could be the main hypothesis to explain this phenomenon.

The third phase consisted in a steady-state (loss of high variability) of the reservoir in terms of biomass, abundances and taxonomic richness. Populations were dominated by a few species adapted to this new aquatic ecosystem. These species were mainly cyprinids like Hampala macrolepidota. The success of this adaptation was mainly related to the plasticity of this species in terms of food resource and reproduction. In fact, this cyprinidae should spend its entire life cycle in the reservoir (Poulsen et al., 2004). Few other species originated from the Nam Theun area (eiver and surrounding ponds), composed this new reservoir fish population. These species belonged to e.g. Oreochromis niloticus and Channa striata and are commonly found in reservoirs in Southeast Asia (Kolding \& van Zwieten, 2006; Thapanand et al., 2007; Zacharia et al., 2010).

A stable state of the fish population of the reservoir was not yet reached as fish population changes were still on-going. Additionally, maturation of the fish population varies according the reservoir itself. Petr (1978) indicated that the stabilised age of a man-made reservoir was considered only when minor changes in fish population occurred. This age was estimated for tropical lakes at 8+ years (Balvay, 1985), and 5 to 10 years for temperate reservoirs (e.g. United States reservoirs, Kimmel \& Groeger, 1986; Agostinho et al., 1999). Furthermore, recent introduction of new species e.g. the potential invasive chandidae Parambassis siamensis, will definitely influence the future evolution of the fish population in the NT2 Reservoir.

In the transition area (NTH2) and the river upstream (NTH1), two phases appeared in terms of fish population evolution since the impoundment in 2008. The first phase (2008-2010) corresponded to a decline in the population (taxonomic richness, biomass, and abundance). On the Nam Theun catchment, backwaters affected the upstream fish population in terms of diversity and abundance. The impoundment of the reservoir has affected some species by limiting their progress to reach the spawning and growing areas within the watershed (e.g. R. paviei, Cyclocheilichthys spp.). However, the hydrology and more particularly the flooding events are also recognized to influence fish population of the subsequent year (Visser et al., same issue). For instance, the low rainy season of 2008 and the late rainy season and flooding event of 2010 (Descloux et al., same issue) could have participated in the decline observed the subsequent campaign. Then, the influence of the impoundment on the fish 
population in the upstream river could not be clearly underlined.

The second phase started in 2011 with an improvement of fish population metrics. During the WD seasons an increase occurred in terms of biomass, abundance and taxonomic richness in the Nam Theun upstream. The long rainy season 2011 (Descloux et al., same issue) may have played an important role in the increase of fish productivity in 2012 in the river upstream. Nevertheless, species composition shifted with the colonisation of permanent species e.g. Cirrhinus molitorella, Barbonymus gonionotus found in the transition area. Some species disappeared or became scarce (e.g. Devario fangfangae, Hemiculterella macrolepis, Rhodeus laoensis, and Tor tambroides). However, their presence (as well as other endemic species) was confirmed in the Nam Theun River upstream (several kilometres upstream of NTH1) during a fish biodiversity survey (Kottelat, 2012). On the other hand, a rapid improvement of the fish population (only 2 years) resulted in an increase of abundance, biomass, and the taxonomic richness in the transition area for both seasons. Species achieving small-scale migration during the reproduction period (WW season) are then recorded e.g. with the catch of the Cyprinidae Cyclocheilichthys spp. and P. brevis or the snakehead fish Channa striata. Some species showed a good adaptation to the transition area and became common in this new environment e.g. Cirrhinus molitorella. Chosen main indicator species $H$. macrolepidota and $P$. carinatus are also adapted to this new environment (e.g. no change in the size spectra and presence of young individuals).

The monitoring underlined that the shoreline of the reservoir and transition areas were important for the young stage of some species (e.g. H. macrolepidota, $O$. niloticus, $P$. siamensis, C. striata). These littoral zones provided a suitable environment with low current and structured habitat in the inundated forest for shelter and for the growth of young individuals. These littoral zones are also known to be often the most productive area within a reservoir (Agostinho et al., 1999).

Finally, oxygen stress is a wellknown phenomenon occurring in newly impounded reservoirs (de Mérona et al., 2001). Higher demand of oxygen related to the degradation of the flooded organic matter involves oxygen depletion in the water system. This event could affect fish population, with, in the worst-case scenario, appearance of fish kill events (e.g. Brokopondo Reservoir, Mol et al., 2007). This phenomenon is generally a consequence of reservoir turnovers. NT2 Reservoir annual turnovers (Chanudet et al., same issue) did not lead to an anoxic water column. The reservoir showed surface water with a level of dissolved oxygen compatible with aquatic life since the beginning of the monitoring. However, few localized and time-limited dissolved oxygen depletion events were recorded (Fig. 3, Chanudet et al., same issue). As a consequence, limited fish kills were recorded in the transition area between the WD seasons and WW seasons in 2009 and 2011 implying a few dozen of individuals. At this period of the year (end of the WD season) and at this particular location, 
the reservoir was at its lowest level with a stable stratification with an anoxic and warm hypolimnion. The sudden flow input with cooler temperature, brought the hypolimnion towards the epilimnion and generated localised overturns, leading to a sudden anoxia in localised areas where fish have been trapped. Even if the risk of such events decreases with time, a potential occurrence still exists every year in these particular areas.

\subsection{Relation between environment, habitat and fish}

The NT2 Reservoir is divided in three main water systems, which are the reservoir, the transition area and the rivers. The study over two years 2012-2013 showed a clear difference in population according to the aquatic system, the habitat, the presence of villages, and the season.

Higher catches tended to be found in areas with a structured habitat (e.g. dense forest), which are found close to some areas of the reservoir (e.g. RES3) and in all transition areas for both seasons (WD and WW, PCA analyses results). Inundated trees provide a more complex habitat used for shelter and provide a greater availability and heterogeneity of food resources (Jackson et al., 2001; Agostinho et al., 2008). Trees are a good support for food resource like biofilms and aquatic invertebrates. Furthermore, a structured shoreline is known to be an important factor for the nest-building fish (O’Brien, 1990; Bettoli et al., 1993) and enhancing the success of reproduction. Field observations underlined this higher fish colonisation of the flooded forest. When nets were set too far from the inundated forest and more in the pelagic zone (e.g. near old Nam Theun River mainstream), only few fish species were caught compared to area with structured habitat. This indicated that only few species colonised this new habitat (open area) in the reservoir such as $O$. niloticus. This species showed a successful colonisation of this new vacant habitat (pelagic zone) as observed in other tropical reservoirs (Fernando \& Holčík, 1991; Kolding \& van Zwieten, 2006). Apart from their high biological and physiological plasticity to environmental changes, the success of this colonisation came also from the ability of adults to feed on the planktonic items (Mol et al., 2007). However, some reservoir stations with structured habitat (e.g. medium forest in RES4) presented a same range of catch compared to stations with less structured habitat (RES8 and RES12). This lower catch in an area previously described as productive (presence of structured habitat) can be explained by the fishing pressure in this specific zone close to villages.

The transition area offers a combination of structured habitat (inundated forest) and an environment suitable for riverine species (e.g. semi-lotic environment) (de Oliveira et al., 2005). This area appeared to be rich in terms of biomass and taxonomic richness. We can suppose that fish population established in these systems takes advantage of both the reservoir system (e.g. inundated forest) and the river system (higher flooding rate, shallow area) (e.g. C. molitorella, Cyclocheilichthys spp., $R$. paviel). The highest fish 
productivity in transition area reflected the colonisation of species showing a greater plasticity in their biological cycle (Agostinho et al., 2008).

\section{CONCLUSION}

Two years after impoundment, the upstream river system and the transition areas showed an improvement of the fish population with an increase in terms of biomass, abundances and taxonomic richness. The fish population of the NT2 Reservoir area showed an evolution divided into three phases. This phenomenon was expected, but the population of the reservoir changed rapidly compared to other newly impounded reservoirs. The approach aquatic system - habitat - fish catch showed that the flooded forest influenced positively the fish population, especially in transition area. The littoral zone of the reservoir also appeared to be an important area for fish production. The Nam Theun 2 Reservoir is at its early stage of fish population stabilisation mainly in term of biomass and taxonomic richness. Identification of the productive areas at this early stage is a good asset for fish population management which is used for fishery purpose. This will help the sustainability of fisheries by defining important production areas, but also, by the monitoring of newly introduced exotic and potentially invasive species (e.g. P. siamensis). The NT2 Reservoir could follow the same trend as observed in other reservoirs in Asia, which implies the development of exotic species.

\section{ACKNOWLEDGEMENT}

This research has been conducted at the Aquatic Environment Laboratory of Nam Theun 2 Power Company in Lao PDR whose Shareholders are Électricité de France, Lao Holding State Enterprise and Electricity Generating Public Company Limited of Thailand.

We would like to thanks all the NTPC teams for their support during the 6 years monitoring with a special thanks to the hydrobiology and chemistry team from the WQB Dept, Liankham Payasane (GIS team) and the logistic team and their useful boat drivers. We would like also to address a special thanks to Khamtanh Vatthanatham (NTPC) for sharing his knowledge on fisheries in Lao PDR, Monette Véran (Museum National d'Histoire Naturelle de Paris), and especially Dr Maurice Kottelat for his precious advice on fish identification and biodiversity in the Nam Theun area. We also would like to thank Mr Paul Dumbrell who reviewed and improved this version of the manuscript as a native English speaker and reviewers for their comments and helpful advices to improve the manuscript.

\section{REFERENCES}

Agostinho A.A., Miranda L.E., Bini L.M., Gomes L.C., Thomaz S.M. \& Suzuki H.I., 1999. Patterns of colonization in neotropical reservoirs, and prognoses on aging. In: Tundisi J.G. \& Straškraba M. (Eds.), Theoretical Reservoir Ecology And Its Applications, 227-265. 
Agostinho A.A., Pelicice F.M. \& Gomes L.C., 2008. Dams and the fish fauna of the Neotropical region: impacts and management related to diversity and fisheries. Braz. J. Biol. 68 : 1119-1133.

Baird I.G. \& Flaherty M.S., 2005. Mekong River fish conservation zones in Southern Laos: assessing effectiveness using local ecological knowledge. Environ. Manage. $36:$ 439-454.

Balvay G., 1985. Structure et fonctionnement du réseau trophique dans les retenues artificielles. Gestion piscicole des lacs et retenues artificielles : 39-66.

Baxter R.M., 1977. Environmental effects of dams and impoundments. Ann. Rev. Ecol. Syst. 8 : 255-283.

Bettoli P.W., Maceina M.J., Noble R.L., \& Betsill R.K., 1993. Response of a reservoir fish community to aquatic vegetation removal. N. Am. J. Fish. Manage. $13: 110-124$.

Chanudet V., Fabre V. \& Van Der Kaaij T., 2012. Application of a three-dimentional model to the Nam Theun 2 Reservoir (Lao PDR). J. Great Lakes Res. 38 : 260-269.

Chanudet V., Guédant P., Rode W., Guérin F., Serça D., Deshmukh C. \& Descloux S. Evolution of the physico-chemical water quality in the Nam Theun 2 Reservoir for the first 5 years after impoundment. Hydroécol. Appl. 19 (same issue).

Crivelli A.J., Grillas P., Jerrentrup H. \& Nazirides T., 1995. Effects on fisheries and waterbirds of raising water levels at Kerkini Reservoir, a Ramsar site in Northern Greece. Environ. Manage. 19 : 431-443.

Descloux S., Chanudet V., Poilvé H. \& Grégoire, A., 2011. Co-assessment of biomass and soil organic carbon stocks in a future reservoir area located in Southeast Asia. Environ. Monit. Assess. $173: 723-741$.
Descloux S., Guédant P., Phommachanh D. \& Luthi R. Main features of the Nam Theun 2 hydroelectric project (Lao PDR) and the associated environmental monitoring programme. Hydroécol. Appl. 19 (same issue).

Fernando C.H. \& Holčík J., 1991. Fish in Reservoir. Int. Rev. Ges. Hydrobiol. 76 (2) : 149-167.

De Freitas Terra B. \& Araújo F.G., 2001. A preliminary fish assemblage index for a transitional river-reservoir system in southeastern Brazil. Ecol. Indic. 11 : 874-881.

Jackson D.A., Peres-Neto P.R., \& Olden J.D., 2001. What controls who is where in freshwater fish communities - the roles of biotic, abiotic, and spatial factors. Can. J. Fish. Aquat. Sci. 58 : 157-170.

Kang B., Perrett L., Yungang L. \& He D., 2009. Are the fish of the upper and lower Mekong interconnected? Chin. J. Oceanol. Lymnol. 27 : 400-407.

Kimmel B.L. \& Groeger A.W., 1986. Limnological and ecological changes associated with reservoir aging. Reservoir Fisheries Management: Strategies for the 80's, 103-109.

Kolding J. \& van Zwieten P.A.M., 2006. Improving productivity in tropical lakes and reservoirs. Challenge Program on Water and Food. Aquat. Ecosyst. Fish. Rev. Series 1. Worldfish Center, $139 \mathrm{p}$.

Kottelat M., 1998. Fishes of the Nam Theun and Xe bangfai basins, Laos, with diagnoses of twenty-two new species (Teleostei: Cyprinidae, Balitoridae, Cobitidae, Coiidae and Odontobutidae). Ichthyol. Explor. Freshwaters 9 : 1-128.

Kottelat M., 2001. Fishes of Laos, WHT publications, $198 \mathrm{p}$.

Kottelat M., 2012. Post-impoundment fish biodiversity survey 2012. NTPC Final Report, Contract C2003 : 119 p. 
Kubečka J., 1993. Succession of fish communities in reservoirs of Central and Eastern Europe. Comparative Reservoir Limnology and Water Quality Development. Dev. Hydrobio 77 : 153-168.

Lelek A., 1973. Sequence of changes in fish populations of the new tropical manmade lake, Kainji, Nigeria, West Africa. Arch. Hydrobiol. 71 : 381-420.

Lévêque C., Oberdoff J., Paugy D., Stiassny M.L.J. \& Tedesco P.A., 2008. Global diversity of fish (Pisces) in freshwater. Hydrobiol. 595 : 545-567.

Martinet M., Guédant P. \& Descloux S. Phytoplankton community and trophic level assessment of a newly impounded subtropical reservoir: case study of the Nam-Theun 2 Reservoir (Lao PDR, South-East Asia). Hydroécol. Appl. 19 (same issue).

de Mérona B., 2002. Dynamique des peuplements de poissons dans le réservoir de Petit Saut (fleuve Sinnamary, Guyane française). Bull. Fr. Pêche Piscic. $364: 5-22$.

de Mérona B., 2005. Le fleuve, le barrage et les poissons - Le Sinnamary et le barrage de Petit-Saut en Guyane française, IRD Edt, Paris, 135 p.

de Mérona B., dos Santos G.M. \& de Almeida R.G., 2001. Short term effects of Tucuruí Dam (Amazonia, Brazil) on the trophic organization of fish communities. Environ. Biol. Fish. 60 : 375-392.

de Mérona B., Vigouroux R. \& Horeau V., 2003. Changes in food ressources and their utilization by fish assemblages in a large tropical reservoir in South America (Petit Saut Dam, French Guiana). Acta Oecologica, 24 (24) : 147-156.

Mol J.H., de Mérona B., Ouboter P.E. \& Sahdew S., 2007. The fish fauna of Brokopondo Reservoir, Suriname, during 40 years of impoundment. Neotrop. Ichthyol. 5 (3) : 351-368.
MRC, 2010. State of the Basin Report 2010. Mekong River Commission, Vientiane, Lao PDR, $123 \mathrm{p}$.

Okada E.K., Agostinho A.A., \& Gomes L.C., 2005. Spatial and temporal gradients in artisanal fisheries of a large neotropical reservoir, the Itaipu Reservoir, Brazil. Can. J. Fish. Aquat. Sci. 62 : 714-724.

O'Brien J.W., 1990. Perspectives on fish in reservoir limnology. In: Kimmel B.L., Thornton K.W. \& Payne F.E. (Eds.), Reservoir Limnology: Ecological Perspectives, 209-225.

de Oliveira E.F., Minte-Vera C.V., \& Goulart E., 2005. Structure of fish assemblages along spatial gradients in a deep subtropical reservoir (Itaipu Reservoir, Brazil-Paraguay border). Environ. Biol. Fish. 72 : 283-304

Petr T., 1978. Tropical man-made lakes their ecological impact. Arch. Hydrobiol. 81 : 368-385.

Poddubny A.G. \& Galat D.L., 1995. Habitat associations of upper Volga river fishes: effects of reservoirs. Reg. Riv. Res. Manage. $11: 67-84$.

Poulsen A.F., Hortle K.G., Valbo-Jorgensen J., Chan S., Chhuon C.K., Viravong S., Bouakhamvongsa K., Suntornratana U., Yoorong N., Nguyen T.T. \& Tran B.Q., 2004. Distribution and ecology of some important riverine fish species of the Mekong River Basin. MRC Technical paper $10.116 \mathrm{p}$.

Rainboth W.J., 1996. FAO species identification field guide for fishery purposes. Fishes of the Cambodian Mekong. Rome, FAO, $265 \mathrm{p}$.

Souksavath S. \& Nakayama M., 2013. Reconstruction of the livelihood of resettlers from the Nam Theun 2 hydropower project in Laos. Int. J. Water. Resources Dev. 29 (1) : 71-86.

Thapanand T., Moreau J., Jutagate T., Wongrat P., Lekchonlayuk T., Meksumpun C., Janekitkarn S., Rodloi A., Dulyapruk A. \& Wongrat L., 2007. Towards possible 
fishery management strategy in a newly impounded man-made lake in Thailand. Ecol. Model. 204 : 143-155.

Travade F., Enderle M.J. \& Gras R., 1985. Retenues artificielles: gestion hydraulique et ressources piscicoles. Gestion piscicole des lacs et retenues artificielles : $15-37$.

Vidthayanon C., 2008. Field Guide to fishes of the Mekong delta. Mekong River Commission, Vientiane, $288 \mathrm{p}$.

Visser T.A.M., Ovenden M., Wongwai N. Developing approaches for establishing a fisheries baseline: case-study for $\mathrm{Xe}$ Bangfai basin (Lao PDR). Hydroécol. Appl. 19 (same issue).

Williams J.D., Winemiller K.O., Taphorn D.C. \& Balbas L., 1998. Ecology and status of piscivores in Guri, an oligotrophic tropical reservoir. N. Am. J. Fish. Manage. $18: 274-285$.

Yi Y., Yang Z. \& Zhang S., 2010. Ecological influence of dam construction and riverlake connectivity on migration fish habitat in the Yangtze River basin, China. Proc. Environ. Sci. 2 : 1942-1954.

Zacharia M.Z., Jalal K.C.A. \& Ambak M.A., 2010. Length weight relationship and relative condition factor of Sebarau, Hampala macrolepidota (Van Hasselt) in Kenyir Lake, Malaysia. Pak. J. Bio. Sci. 3 : 721-724.

Zhong Y. \& Power G., 1996. Environmental impacts of hydroelectric projects on fish resources in China. Reg. Riv. Res. Manage. 12 : 81-98. 
Appendix 1. Photography of the main species encountered in the Nam Theun 2 area.

Appendix 1. Photographies des principales espèces rencontrées au niveau de Nam Theun 2.

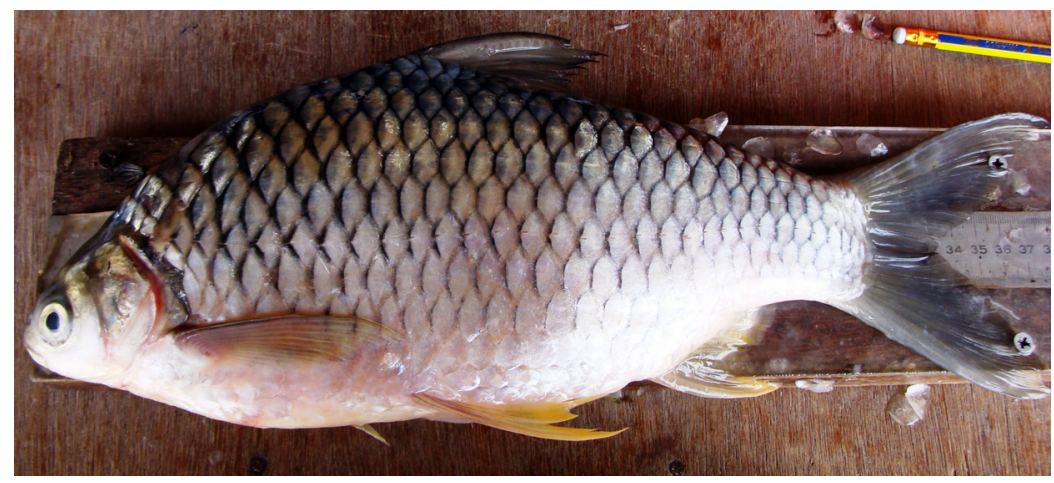

Photo 1. Barbonymus gonionotus

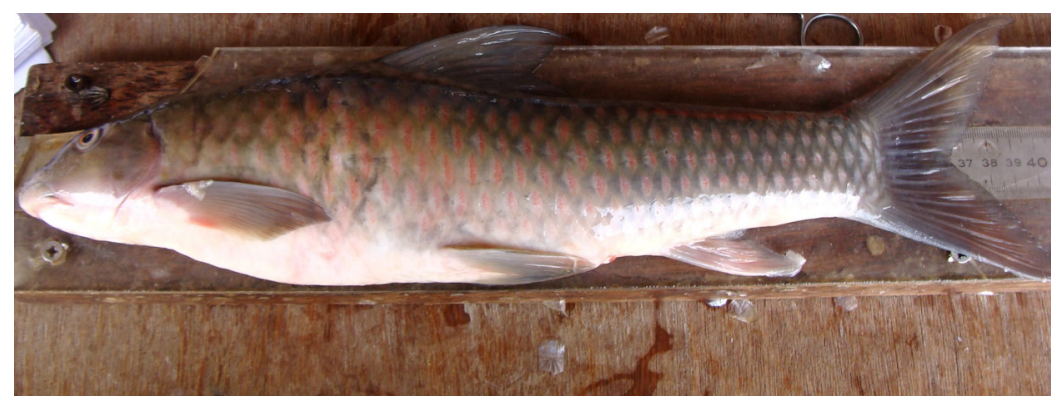

Photo 2. Bangana elegans

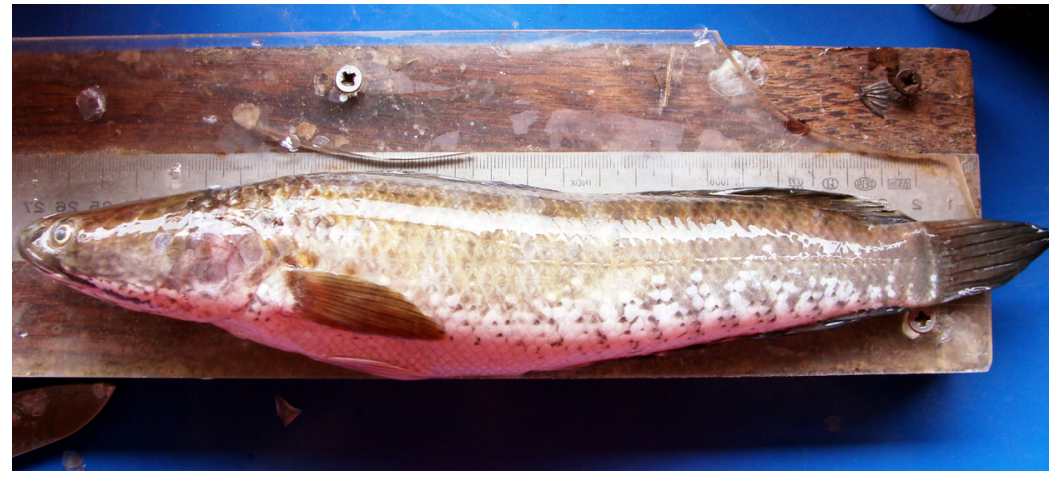

Photo 3. Channa striata 


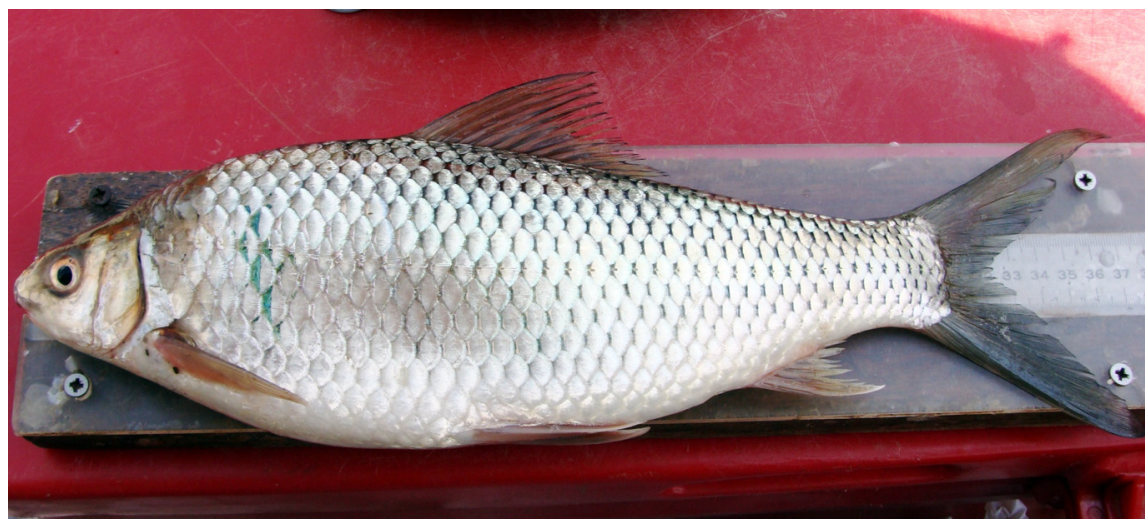

Photo 4. Cirrhinus molitorella

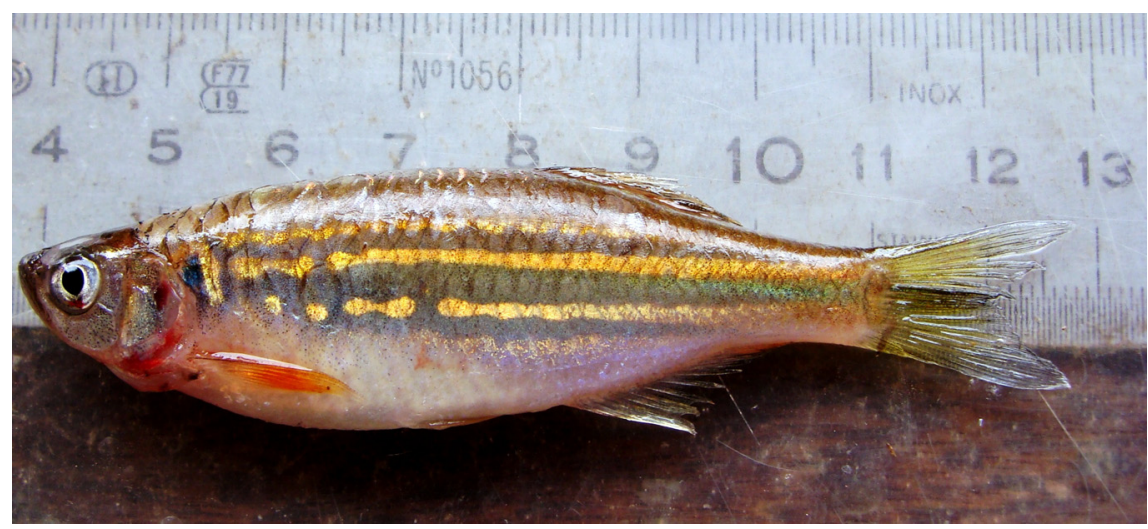

Photo 5. Devario fangfangae

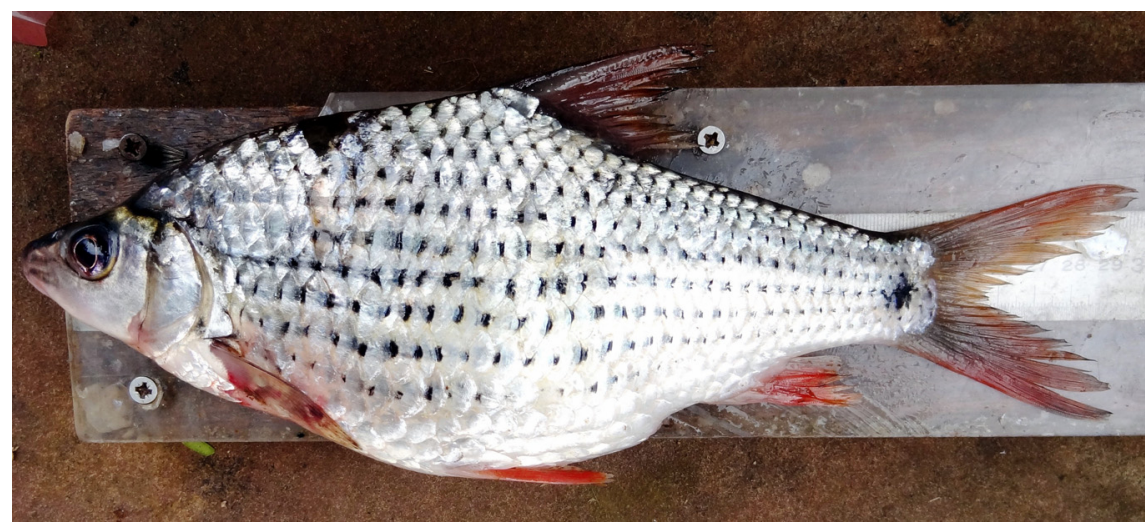

Photo 6. Cyclocheilichthys repasson 


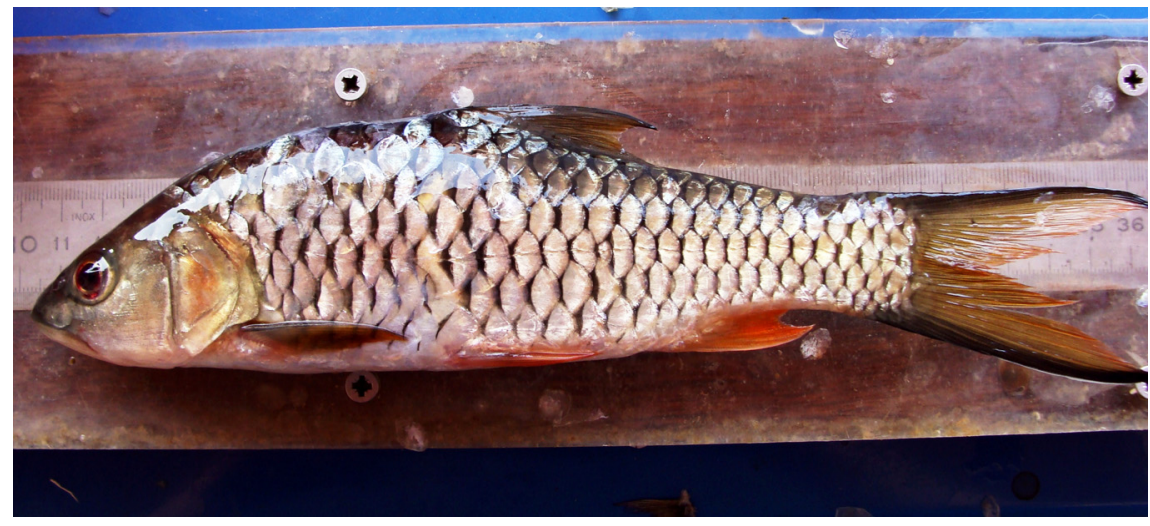

Photo 7. Hampala macrolepidota

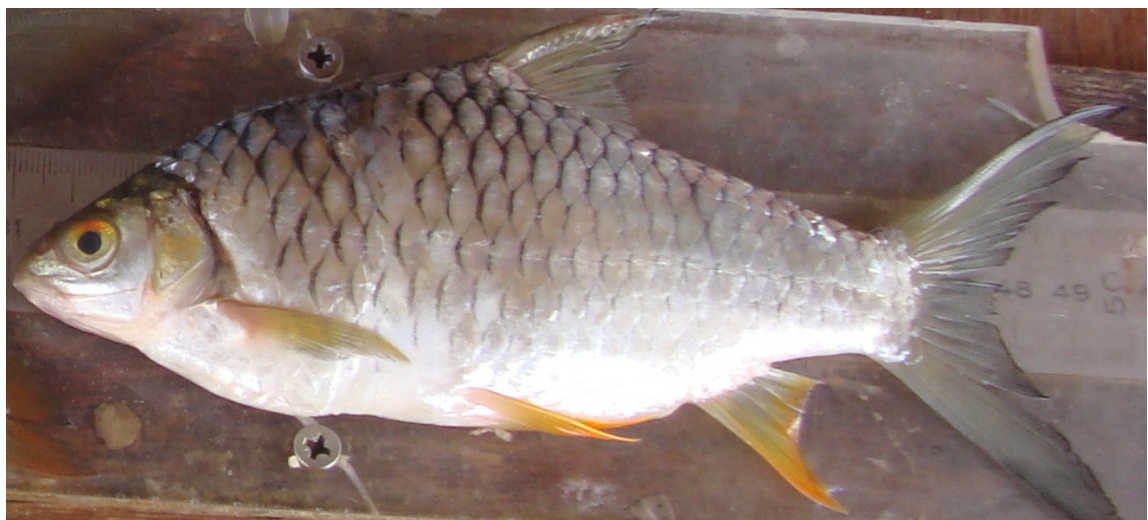

Photo 8. Hypsibarbus vernayi

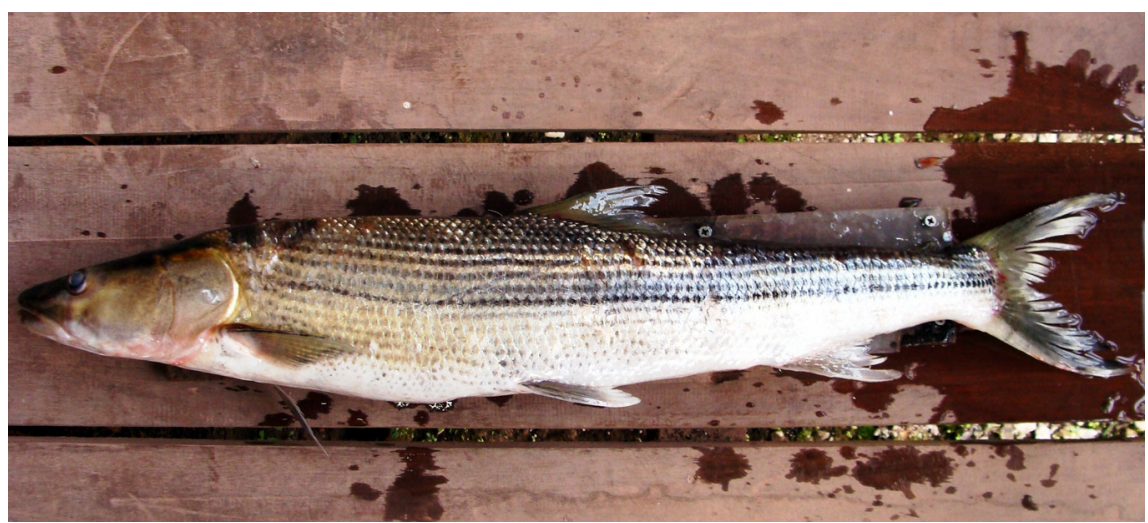

Photo 9. Luciocyprinus striolatus 


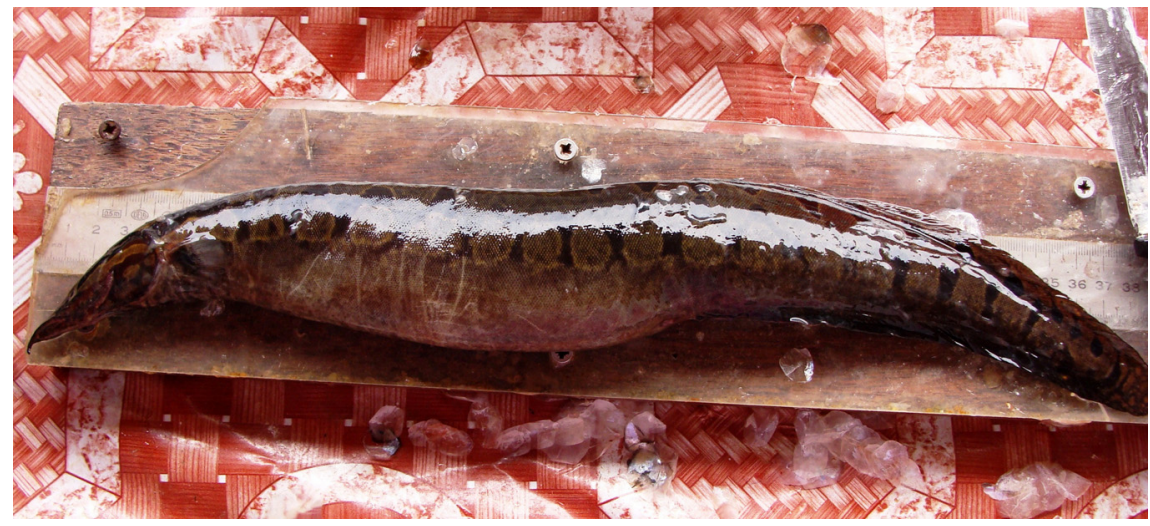

Photo 10. Mastacembellus armatus

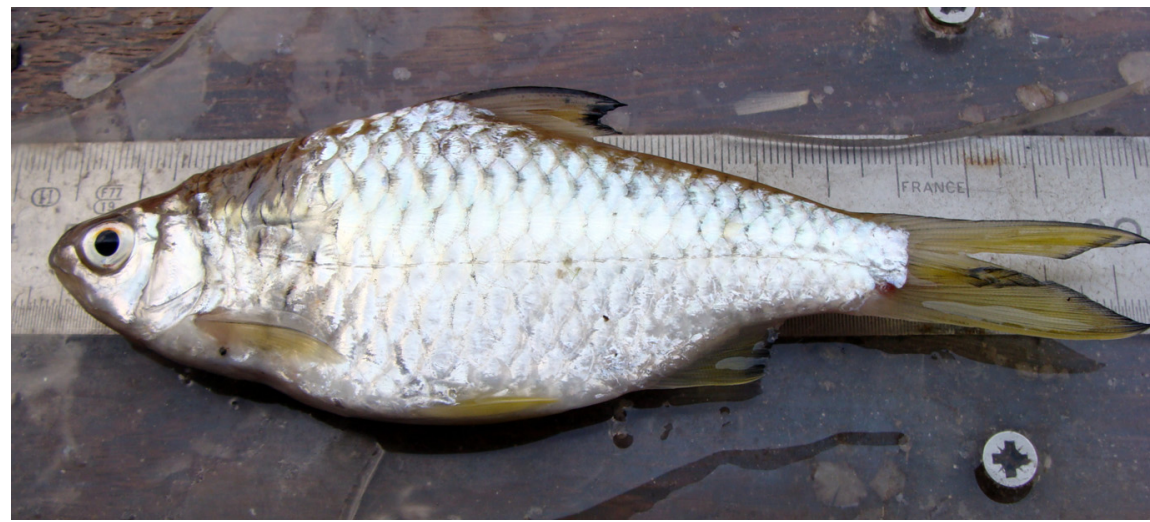

Photo 11. Mystacoleucus marginatus

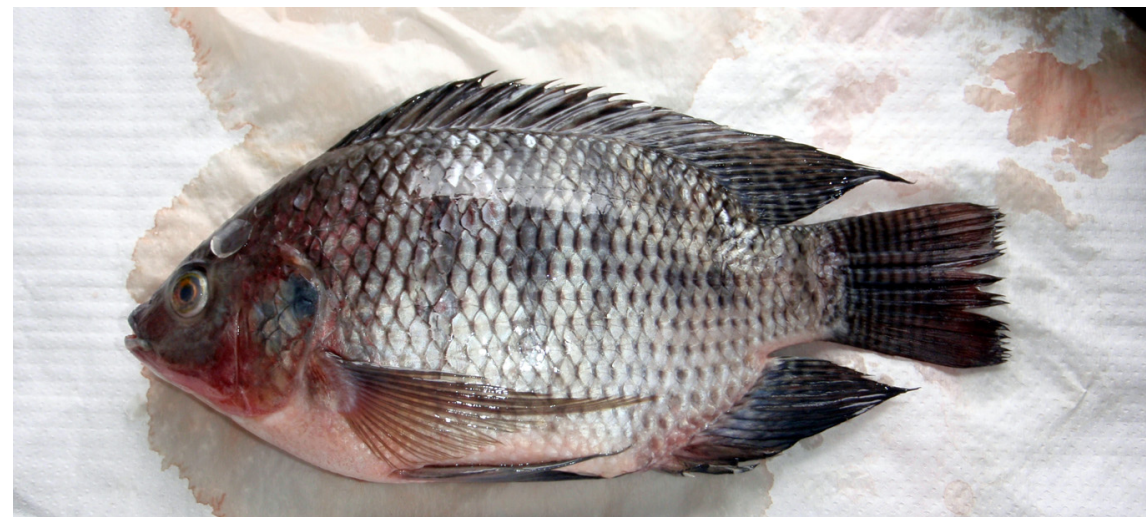

Photo 12. Oreochromis niloticus 


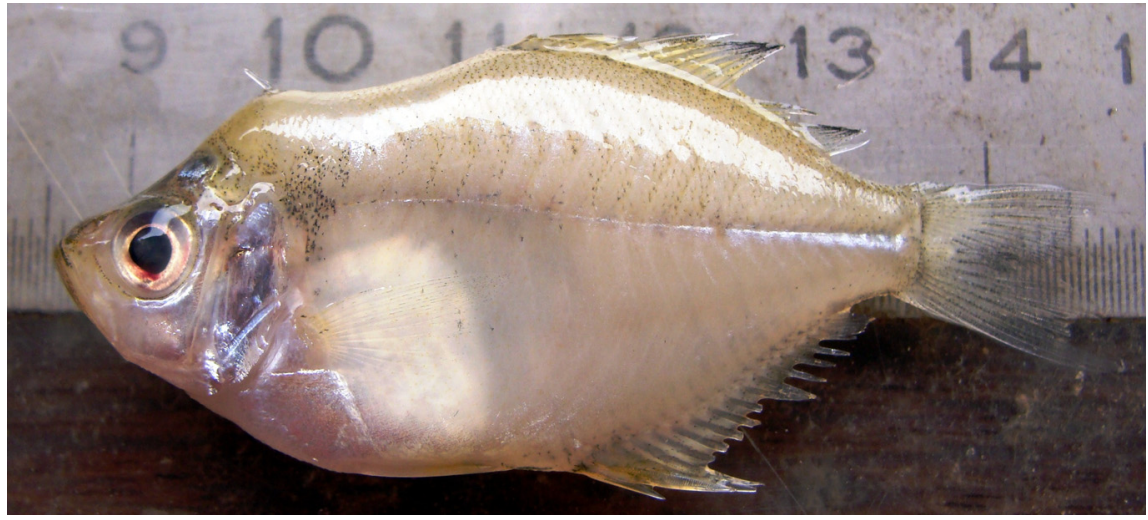

Photo 13. Parambassis siamensis

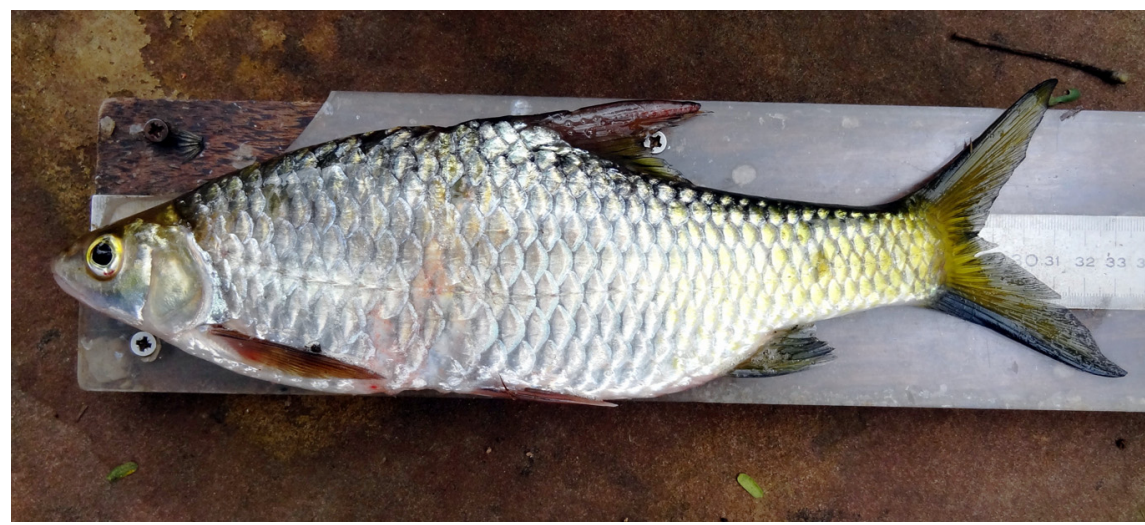

Photo 14. Poropuntius carinatus

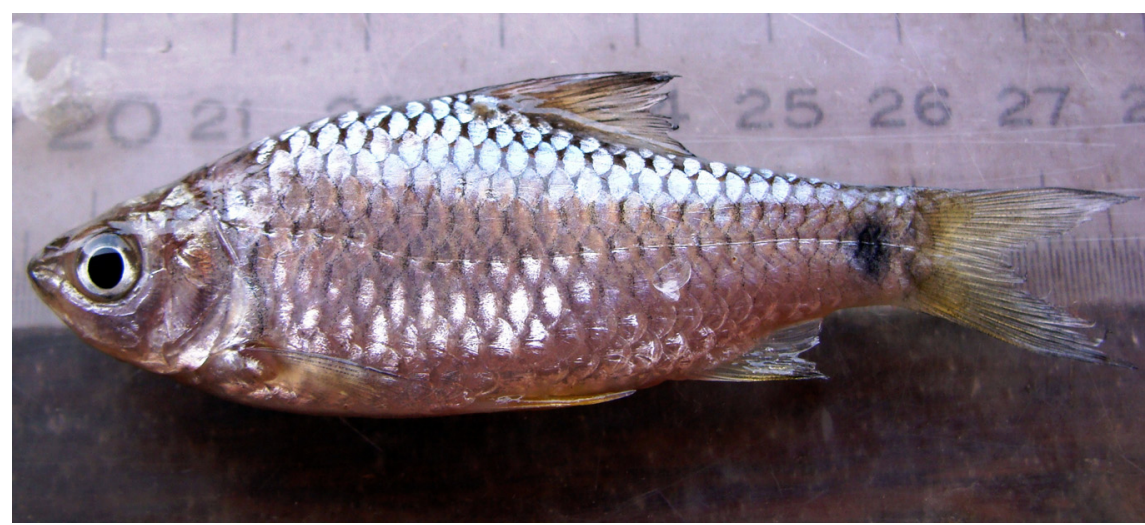

Photo 15. Puntius brevis 


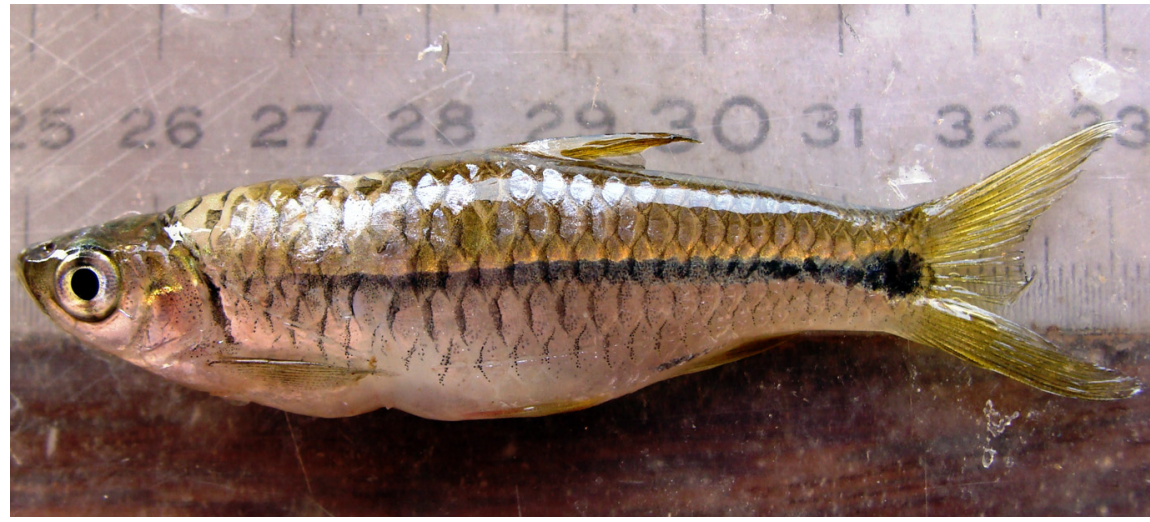

Photo 16. Rasbora paviei 